\title{
CORPORATE IMMUNITY TO THE COVID-19 PANDEMIC
}

\author{
Wenzhi Ding \\ Ross Levine \\ Chen Lin \\ Wensi Xie \\ Working Paper 27055 \\ http://www.nber.org/papers/w27055
NATIONAL BUREAU OF ECONOMIC RESEARCH 1050 Massachusetts Avenue
Cambridge, MA 02138
April 2020

The views expressed herein are those of the authors and do not necessarily reflect the views of the National Bureau of Economic Research.

NBER working papers are circulated for discussion and comment purposes. They have not been peer-reviewed or been subject to the review by the NBER Board of Directors that accompanies official NBER publications.

(C) 2020 by Wenzhi Ding, Ross Levine, Chen Lin, and Wensi Xie. All rights reserved. Short sections of text, not to exceed two paragraphs, may be quoted without explicit permission provided that full credit, including (C) notice, is given to the source. 
Corporate Immunity to the COVID-19 Pandemic

Wenzhi Ding, Ross Levine, Chen Lin, and Wensi Xie

NBER Working Paper No. 27055

April 2020

JEL No. F23,G3,I10,M12,M14

\section{ABSTRACT}

Using data on over 6,000 firms across 56 economies during the first quarter of 2020, we evaluate the connection between corporate characteristics and stock price reactions to COVID-19 cases. We find that the pandemic-induced drop in stock prices was milder among firms with (a) stronger pre-2020 finances (more cash, less debt, and larger profits), (b) less exposure to COVID-19 through global supply chains and customer locations, (c) more CSR activities, and (d) less entrenched executives. Furthermore, the stock prices of firms with greater hedge fund ownership performed worse, and those of firms with larger non-financial corporate ownership performed better. We believe ours is the first paper to assess international, cross-firm stock price reactions to COVID-19 as functions of these pre-shock corporate characteristics.

Wenzhi Ding

University of Hong Kong

Hong Kong

wenzhi.ding@connect.hku.hk

Ross Levine

Haas School of Business

University of California at Berkeley

545 Student Services Building, \#1900 (F685)

Berkeley, CA 94720-1900

and NBER

Ross_levine@haas.berkeley.edu
Chen Lin

Faculty of Business and Economics

The University of Hong Kong

Hong Kong

chenlin1@hku.hk

Wensi Xie

Department of Finance

Chinese University of Hong Kong

Hong Kong

wensixie@cuhk.edu.hk 


\section{Introduction}

The global economic crisis triggered by COVID-19 is different from past crises. Former Chair of the U.S. Federal Reserve, Ben Bernanke (2020), stressed that while financial imbalances and risks grew over many years to produce the 2008 global financial crisis, the COVID-19 crisis was caused by a viral pandemic that abruptly and severely constricted global economic activity. Carmen Reinhart (2020)—who along with Kenneth Rogoff (2009) documented the striking similarities of crises during the eight centuries prior to COVID-19—recently emphasized that the COVID-19 crisis is truly different from past crises with respect to the cause, scope, and severity. These observations motivate research into the factors shaping the response of countries, firms, and individuals to the COVID-19 crisis. In this paper, we examine the resilience of firms to the pandemic, focusing on the differential, cross-firm stock price reactions to COVID-19 cases.

The COVID-19 pandemic has triggered enormous-and heterogeneous-stock price movements. During the first quarter of 2020, the S\&P 500 fell by $34 \%$ from its high to its low, while the exchanges in Brazil, Hong Kong, Italy, and Japan experienced high-low declines of 46\%, $25 \%, 42 \%$, and $31 \%$, respectively. There have also been large differences in stock price movements across firms within the same industry and country. For example, the average U.S. manufacturing firm saw stock prices fall by $29 \%$ over the first quarter with a standard deviation of $24 \%$, and where similar cross-firm heterogeneity exists among more refined industrial categories. These developments raise the question, which firm characteristics make some companies more "immune" to the COVID-19 shock than others?

In this paper, we examine the relationship between pre-2020 corporate characteristics and stock price reactions to the COVID-19 pandemic. Using theories of the corporation to frame our study and data on over 6,000 firms across 56 economies during the first quarter of 2020, we consider five pre-2020 firm traits: (1) basic financial conditions, such as cash holdings, leverage, and profitability, (2) international supply chain and customer exposure to COVID-19, such as the degree to which a firms' inputs are purchased from and products sold in countries differentially exposed to COVID-19, (3) corporate investment in corporate social responsibility (CSR), such as 
relations with employees, suppliers, customers, and the communities in which firms operate, (4) corporate governance, such as executive control of the board, antitakeover provisions, and executive compensation systems, and (5) ownership structure, such as the extent to which hedge funds, families, non-financial corporations, and institutional investors hold large stakes in firms. We believe that ours is the first paper to assess cross-firm stock price reactions to COVID-19 as functions of these pre-shock corporate characteristics. By examining these characteristics simultaneously, we can better identify the connection between each corporate characteristic and stock price reactions to the pandemic.

Theories of the firm offer insights into and predictions concerning how these five corporate characteristics shape stock price reactions to the COVID-19 pandemic. The first two traits relate to the severity of firms' liquidity constraints and exposure to the pandemic through business connections. First, given the adverse impact of the pandemic on cash-flows and the tightening of global liquidity demands, heterogeneity in firms' access to cash and credit may influence firm performance and hence market valuations (e.g., Harford 1999; Bates, Kahle, and Stulz 2009; Kahle and Stulz 2013; Pinkowitz, Stulz, and Williamson 2016; Giroud and Mueller 2017). From this perspective, firms with more cash, less leverage, and greater access to credit (e.g., more profitable firms) will experience less severe stock price declines than otherwise identical firms. Second, firms are connected through networks of suppliers and customers (e.g., Long and Plosser 1983; Hertzel et al. 2008; Acemoglu et al. 2012; Acemoglu, Ozdaglar and Tahbaz-Salehi 2017). To the extent that some firms' networks of suppliers and customers are situated in countries more affected by COVID-19 than other firms, those more-affected firms are likely to experience greater disruptions to production and sales and hence larger stock price declines than similar firms with less COVID19 exposure. While policy makers and industry practitioners (e.g., the Chair of the Federal Reserve, Jerome Powell, and the CEO of BlackRock, Larry Fink) have stressed the potential 
impact of global supply chain disruptions on markets, we evaluate empirically firms' stock prices and their exposure to COVID-19 through global supply chains and customer locations. ${ }^{1}$

Third, research suggests that the relationships between a firm and its workers, suppliers, customers, and local community can shape corporate performance and resilience to adverse shocks, including the COVID-19 crisis. Influential theories of the firm (e.g., Coase 1937; Jensen and Meckling 1976) view the firm as a nexus of contracts between shareholders and other stakeholders, who provide the firm with resources in exchange for claims, typically defined by explicit contracts that are enforced by formal legal systems. Arrow (1972), Putnam (1993), La Porta et al (1997), Knack and Keefer (1997), and Guiso, Sapienza, and Zingales (2004, 2008) explain that most business arrangements cannot effectively and efficiently be contracted for and enforced only through formal contracts and legal systems, so that most commercial transactions rely to some degree on trust. From this perspective, a corporation's performance depends on the trust that it has established with various stakeholders. Firms can strengthen their connections with these stakeholders through CSR activities, such as creating safe, healthy workplaces, engaging in ethical business practices, providing enduring, reliable services to customers, and investing in the local environment and community more generally. Such CSR activities signal a firm's commitment to satisfying implicit contracts, which in turn boosts stakeholders' willingness to support a firm's operations, especially in difficult times (Deng, Kang, and Low 2013). Furthermore, as shown by Albuquerque, Koskinen, and Zhang (2019), CSR activities strengthen customer loyalty and hence reduce a corporation's susceptibility to economic downturns. Thus, CSR can strengthen the web of connections underlying efficient-and resilient-corporate activities, as found by Lins, Servaes, and Tamayo (2017). ${ }^{2}$ There are, however, countervailing

1 See, for example, https://www.cnbc.com/2020/03/03/powell-says-the-fed-saw-a-risk-to-the-outlook-for-theeconomy-and-chose-to-act.html; and https:/www.bloomberg.com/news/articles/2020-03-30/fink-sees-economyrecovering-from-virus-but-forever-transformed.

${ }^{2}$ Lins, Servaes, and Tamayo (2017) show that high-CSR firms in the United States enjoyed better stock returns during the 2008 financial crisis. Our work complements their study. We focus on the global economic crisis triggered by COVID-19, conduct the analyses in an international setting, and examine CSR as one of a constellation of corporate characteristics that might shape stock price reactions to the pandemic. 
views. Other research suggests that CSR activities provide private benefits to executives by enhancing their reputations with politicians, foundations, charitable organizations, and other associations at the expense of shareholders (e.g., Tirole 2001; Pagano and Volpin 2005; Benabou and Tirole 2010; and Masulis and Reza 2015). From this perspective, more CSR activities may not enhance and could even be associated with less resilient stock prices.

Fourth, the structure of corporate governance, managerial entrenchment, and executive compensation systems may also influence market perceptions of a corporation's resilience to COVID-19. For example, given uncertainty about the magnitude and duration of the pandemic, markets might put a premium on flexibility, including mergers and acquisitions and leadership changes (Jensen 1988; Jensen and Ruback 1983). This would suggest that corporations with preexisting antitakeover devices or other governance structures that protect executives would experience harsher stock price reactions to the pandemic (Shleifer and Vishny 1997; Gompers, Ishii, and Metrick 2003; Cremers and Nair 2005; Harford, Mansi, and Maxwell 2008; Bebchuk, Cohen, and Ferrell 2009; Giroud and Mueller, 2011). Theories of tunneling also suggest that periods of great uncertainty and tumult can hinder monitoring and create opportunities for insiders to extract greater resources and rents at the expense of other stakeholders (e.g., La Porta et al. 2000; Johnson et al. 2000; Djankov et al. 2008). This view would also predict that as the COVID19 pandemic spread during the first quarter of 2020, stock markets would penalize firms with stronger takeovers devices. Finally, extensive research explores how the structure of corporate boards and executive compensation policies shape corporate performance (e.g., Hermalin and Weisbach 1998, 2003, 2017; Schwartz-Ziv and Weisbach 2013; Guo and Masulis 2015; Jensen and Murphy 1990; Fahlenbrach and Stulz 2011; Beltratti and Stulz 2012; Murphy 2013; Rau 2015). ${ }^{3}$ We focus on resilience, and assess the connection between stock price reactions to the

\footnotetext{
${ }^{3}$ In addition to financial and governance structures, existing research also investigates how firms' internal organizational structure affects the response to an economic crisis. For example, Aghion et al. (2017) show that firms that delegate more power from the headquarters to local plant managers prior to the Great Recession performed better than other firms.
} 
pandemic and cross-firm differences in corporate board structures and executive compensation systems.

Fifth, corporate ownership can also influence corporate resilience. To the extent that a large proportion of a firm's owners have both deep-pockets and a long-run commitment to the firm, such as a large corporation with a strategic interest in the firm, this could influence the firm's ability to weather the COVID-19 shock. In response to adverse news about COVID-19 cases, therefore, stock prices might fall less among firms with a large, corporate blockholder than among otherwise similar firms with different owners. In contrast, research highlights two interrelated features of hedge funds that could contribute to large, nonfundamental stock price movements in the firms with large hedge fund ownership. First, as discussed in Stein (2009) and Khandani and Lo (2011), hedge funds often employ quantitative trading strategies that can trigger "overcrowding" and fire sale effects on prices. Second, hedge funds often use short-term funding to lever their positions (Lo 2008). As a result, disruptions to liquidity, which occurred during the 2008 financial crisis and the 2020 COVID-19 crisis, can trigger the rapid sale of hedge fund assets, with large, nonfundamental price movements (e.g., Khandani and Lo 2011). Thus, adverse news about COVID-19 cases might induce stock prices to fall more among firms with a large, hedge fund blockholder. Next, consider other institutional blockholders. While pension funds, mutual funds, and investment management firms may have long-run perspectives, they (a) might be less committed to particular firms than strategic investors and (b) might be subject to liquidity shocks and withdrawals of their own. Given the potential importance for corporate ownership on corporate behavior and resilience (e.g., Morck, Shleifer, and Vishny 1988; La Porta et al. 1999; Claessens, Djankov, and Lang 2000; Morck, Wolfenzon, and Yeung 2005; Laeven and Levine 2008; Lin et al. 2011), we examine whether the impact of the pandemic on stock prices varies by the ownership structure of firms and whether conditioning on ownership structure alters the findings on the other corporate characteristics.

To evaluate how corporate characteristics shape stock price reactions to COVID-19, we proceed as follows. The dependent variable is weekly stock returns, which is computed for over 
6,000 firms across 56 economies during the weeks from January $2^{\text {nd }}$ through March $27^{\text {th }}, 2020$. A key input into our set of explanatory variables is COVID19, which is the weekly growth rate of the number of confirmed COVID-19 cases in an economy. As explanatory variables, we interact COVID19 with pre-2020 corporate characteristics to assess how firms' stock returns respond to the pandemic as functions of individual corporate traits.

In our core analyses, we examine how firm-specific traits influence stock price reactions to the pandemic, while controlling for economy-time, industry-time, and firm fixed effects. With these fixed effects, we condition out (a) all time-varying and time-invariant country/economy traits, such as differences in legal and political systems, policy reactions to the crisis, institutions and cultural norms, demographic, geographic, and population density characteristics, and other cross-country traits, and (b) all time-varying and time-invariant industry differences, such as differences in the intensity of required in-person contact with customers, suppliers, and coworkers, that might influence stock price reactions to the pandemic. This allows us to better isolate the differential impact of COVID-19 on stock prices as functions of firms' (1) basic financial conditions, (2) international network of suppliers and customers, (3) CSR, (4) corporate governance systems, and (5) ownership structures.

We discover the following. First, pre-pandemic financial conditions have shaped stock price reactions to COVID-19. Firms with more cash, less debt, and larger profits experienced better stock price performance than otherwise similar firms. As the pandemic depressed corporate sales and firms sought liquidity to cover costs, stock markets considered firms' cash reserves, leverage, and profitability when re-evaluating the value of corporations. The estimated impact of these financial indicators on pandemic-induced stock price changes are robust to conditioning on economy-time, industry-time, and firm fixed effects and to simultaneously controlling for other firm-specific characteristics interacted with COVID19. With respect to magnitudes, our results suggest the following: Comparing two otherwise similar firms, the low-cash firm-the firm with one standard deviation lower pre-2020 ratio of cash-to-assets - would experience an almost $6 \%$ (of the sample mean weekly stock return) extra drop in its stock returns in response to the same 
COVID-19 shock. Using a similar comparison, a high-leverage firm (one standard deviation greater pre-2020 leverage than an otherwise similar firm) would experience an extra 10\% (of the sample mean value of weekly stock returns) drop in stock returns according to our estimates.

Second, the pandemic-induced decline in stock prices has been greater among firms with more exposure to the COVID-19 pandemic through their international supply chains and customers in other countries. To measure this exposure, we compute for each firm in each week (1) Suppliers' exposure as the weighted average of COVID19 for the country from which the firm receives suppliers, where the weights are the proportion of the firm's pre-pandemic supplies from those countries and (2) Customers' exposure as the similarly weighted average of COVID19 for the country in which the firm sells its products. Apparently, markets considered international exposure to the pandemic in revaluing firms. The estimated impacts are large. For example, consider (a) two otherwise similar firms except that one firm has Customers' exposure at the $25^{\text {th }}$ percentile and the other is at the 75th percentile and (b) the two firms operate in the same foreign countries. Holding other factors constant, our estimates imply that the stock price of the more internationally exposed firm would fall by 3.2 percentage points more than the less exposed firm over two months.

Third, CSR matters. Firms that invested more in CSR activities prior to the pandemic enjoyed much better stock price performance in response to the pandemic. These results are consistent with the view that investments in corporate social responsibility build trust with stakeholders, so that workers, suppliers, customers, and other stakeholders are more willing to make adjustments to support the business in response to adverse shocks. The estimated impact is robust and economically large. Besides the multiplicity of fixed effects, we condition on the interaction between COVID19 and each firm's financial condition, international exposure to the pandemic, corporate governance system, and ownership structure. This allows us to focus on the independent influence of CSR investments on stock price resilience to COVID-19. To illustrate the estimated magnitudes, consider two otherwise similar firms in the same industry and economy. One has a pre-2020 CSR score at the $25^{\text {th }}$ percentile and the other is at the 75 th percentile. Our 
estimates suggest that the average stock returns of the high-CSR score firm would decline by 2 percentage points less than the low-CSR score firm in response to the average growth of COVID19 cases two months after the outbreak of the pandemic. Ceteris paribus, these estimates suggest that the stock price reaction to COVID19 for the high-CSR score firm would be $19 \%$ less than the lowCSR score firm.

Fourth, in response to the COVID-19 crisis, markets penalized firms with more entrenched executives. We examined firm-level differences in the use of anti-takeover provisions. We include the interaction of the number of anti-takeover provisions with COVID19. We find that the interaction term enters negatively and statistically significantly. These results suggest that stock markets viewed executive entrenchment negatively in assessing a corporation's comparative immunity to the pandemic. More generally, these findings are consistent with the views that in assessing firms' abilities to respond effectively to the pandemic, markets favorably valued flexibility, including mergers, acquisitions, and leadership changes, and governance structures that limit tunneling. With respect to the magnitudes of the estimated economic effects, consider two otherwise similar firms in an industry. One has pre-2020 Antitakeover Devices at the $25^{\text {th }}$ percentile of the sample distribution of Antitakeover Devices and the other firm is at the 75th percentile. Our estimates suggest that, ceteris paribus, the stock market reactions to COVID19 of the highAntitakeover Devices firm would be $24 \%$ more than the otherwise similar low-Antitakeover Devices firm. We also examine other features of corporate governance, such as detailed measures of the structure of each firm's board of directors and executive compensation policies. We do not find evidence that corporate stock price reactions to COVID-19 vary systematically with board structure or executive compensations systems.

Fifth, we discover strong links between ownership structure and stock price reactions to the COVID-19 pandemic. We focus on the identities of large blockholders, which are entities that own at least $5 \%$ of a firm's shares. First, in response to COVID-19 cases, we find that firms' stock prices fall by less on average when firms are owned more by nonfinancial corporate blockholders. One explanation is that when owners have long-run strategic interests in and commitments to a 
firm, such as a corporate owner, markets price these characteristics positively when evaluating the impact of COVID-19 cases on the firm. Second, we find the opposite for hedge fund ownership. When a larger proportion of a firm's stock is held by a hedge fund, we find that stock prices fall much more in response to COVID-19 cases. This finding is consistent with research by Lo (2008), Stein (2009), and Khandani and Lo (2011), which stresses that the combination of the quantitative trading strategies employed by hedge funds and their reliance on leverage can contribute to sharp, nonfundamental price movements in response to adverse shocks. Third, when examining other types of owners, we do not find a strong connection between the sizes of their ownership stakes and the stock price sensitivity to COVID-19 cases. For example, the interaction terms between COVID19 and different institutional, government, and sovereign wealth fund ownership do enter the stock price regressions significantly in our core analyses. Thus, our findings highlight the ramifications of two particular types of large blockholders, other companies and hedge funds, with large corporate owners providing a ballast against the pandemic's effect on stock prices and stock prices responding more sharply to the pandemic when hedge funds own a large proportion of firms' shares.

We also provide tests of how country characteristics influence stock price reactions to the pandemic. In particular, we change the core analyses by omitting the country-time fixed effects and instead conditioning on particular country-specific factors. This modification allows us to (1) assess the relation between specific country traits and stock returns and (2) evaluate the sensitivity of the results on firm-specific traits to particular country features. We focus on three country traits and discover sharp cross-country differences in the response of stock prices to COVID-19 cases. First, we find that the stock prices of firms in rich countries have weathered the pandemic better than poorer countries. Given the enormous resources necessary to address the public health crisis and the accompanying economic crisis, the financial markets of countries with greater resources have tended to perform much better than poorer countries. Second, stock prices in countries with a larger proportion of the population over the age of 65 declined more sharply than stocks in "younger" countries, perhaps reflecting the greater effect of the pandemic on older people. Third, 
we examine state and media power. One might argue that countries with more centralized state power can more easily abrogate individual rights and effectively respond to COVID-19. Another view stresses that the independent voices of individuals and an active media forced states to address the pandemic. To proxy for state power, we use the country's legal tradition since an influential line of research stresses that civil and socialist legal traditions give greater power to the state than those with common law tradition (Hayek 1960; La Porta et al. 1998, 1999; Levine 2005). Based on insights in Djankov et al. (2003), we use indicators from the World Bank to gauge individual voice and press freedom. Consistent with the view that markets viewed economies with more powerful states as better able to respond to the pandemic, we find that countries with civil and socialist legal traditions experienced smaller stock price declines than those with a common law tradition. With respect to the media, we do not find a robust link between stock price resilience to COVID-19 and indicators of individual voice or press freedom.

\section{Data, Variable, and Sample}

In this section, we describe (1) the time-series, country-specific data on reported cases of coronavirus disease (COVID-19), (2) the stock return data for a large, international sample of publicly-listed firms, and (3) the data on other corporate characteristics, e.g., basic financial conditions, international supply chain exposure, social responsibility, governance, and ownership.

\subsection{COVID-19}

COVID-19 is an infectious disease caused by severe acute respiratory syndrome coronavirus 2. The disease was first identified in December 2019 in Wuhan, China. The first case of the disease outside of China was diagnosed in Thailand in mid-January 2020, and it spread rapidly around the world. The World Health Organization (WHO) declared it a Public Health Emergency of International Concern on January 30, 2020, named the disease COVID-19 on February $11^{\text {th }}$, and classified COVID-19 as a pandemic on March 11, 2020. The total number of confirmed cases around the world is growing at a historically high speed, and has reached more 
than 1.6 million as of April 10, 2020. Figure 1 plots the cumulative coronavirus cases reported in each country/economy at the end of March 2020, demonstrating substantial cross-country differences in the recent spread of COVID-19.

We obtain data on COVID-19 cases from Coronavirus COVID-19 Global Cases Database, which is managed by Dong, Du, and Gardner (2020) at the Center for Systems Science and Engineering (CSSE) at Johns Hopkins University (JHU). The database is organized as an interactive web-based dashboard, tracks the number of new COVID-19 cases around the world in real time, and has been visited more than 15 billion times (as of March 27, 2020), and is used by scholars and media (e.g. Financial Times, BBC). ${ }^{4}$ The JHU team collects daily worldwide data for more than 180 economies, dating back to January 22, 2020. The team assembles information from government reports, local media and online news services, social media platforms, and direct communication with other information sources. It then confirms the case numbers with international health authorities, such as World Health Organization (WHO), and local health departments, such as the respective centers for disease control and prevention.

The case data reported through the CSSE's dashboard includes (1) the number of new confirmed cases, (2) the number of deaths, and (3) the number of recoveries. To measure country exposure to the pandemic, we compute COVID19: the growth rate of the cumulative number of confirmed cases in a country in a given week. To match COVID19 to weekly stock return data, COVID19 is calculated from Saturday to Friday. More specifically, for each country/economy c in week t, we compute COVID19 as follows.

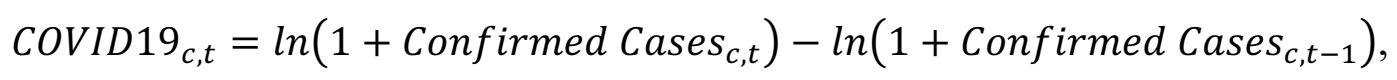

where $c$ and $t$ index country/economy and week. Confirmed Cases $_{c, t}$ represents the cumulative number of confirmed cases in economy $c$ as of Friday in week $t$. Thus, COVID $19_{c, t}$ measures the weekly growth of confirmed cases over week $t$ in economy $c$.

\footnotetext{
${ }^{4}$ See, for example, https://america.cgtn.com/2020/04/03/billions-are-on-this-covid-19-site-we-talked-to-the-guywho-built-it, and https://www.bbc.com/news/world-52120439.
} 
To document the evolution of COVID19, consider Table 1 and Figure 2. As shown in Table 1 , the average value of COVID19 is 1.29 , suggesting that cases were more than doubling each week. Figure 2 illustrates the growth rate in COVID-19 over time by economy, which shows substantial cross-economy, cross-time variation.

\subsection{Stock market data}

We retrieve stock price data during the first quarter of 2020 from the DataStream dataset in Thomson Reuters Eikon. We obtain data on firms in 56 countries, because these are the countries from which we can also obtain data on corporate financial statements (Worldscope) and ESG performance (ASSET4). These countries account for 93\% of world gross domestic product (GDP) and $99 \%$ of global stock market capitalization. Following existing research (e.g., Hanselaar, Stulz, and Van Dijk, 2019), we (a) include stocks that were actively trading in 2020, and (b) calculate weekly stock returns (in percentage) using dividend-adjusted closing prices on the last trading day of the week.

Table 1 and Figure 3 summarize the stock return data. As shown in Table 1, the mean and median weekly returns is $-2.4 \%$ and $-1 \%$ respectively, documenting the general decline in stock prices. Figure 3 illustrates cumulative global stock returns by economy, showing that almost all markets fell by 20 to $40 \%$ from their 2020 high to their 2020 low during the first quarter.

\subsection{Financial conditions}

We retrieve corporate financial data from the Worldscope database of Thomson Reuters Eikon. We use financial data in 2018, which is the most recent year data.

In evaluating how a firm's pre-2020 financial conditions shape its stock price movements

during the COVID-19 pandemic, we consider four basic financial characteristics: Firm Size, Leverage, Cash, and ROA. Firm Size equals the natural logarithm of the book value of total assets. Leverage equals the ratio of total debt divided by total assets. Cash equals the total amount of cash and short-term investments divided by total assets. $R O A$ is the ratio of net income to total assets. 
Given the adverse impact of the pandemic on cash flows and liquidity, preexisting corporate financial conditions may shape the response of stock prices to the evolution of COVID-19 cases.

\subsection{Global supply chain}

We obtain data on firms' international supply chains and customer locations from FactSet Revere database. The Revere database includes information from corporate annual reports and regulatory filings, investor presentations, press releases, websites, and corporate actions. One unique feature of the Revere data is that it contains both direct relationships (relationships disclosed by the reporting company) and reverse relationships (relationships disclosed by companies doing business with the company), so that it offers a relatively comprehensive coverage of companies' global supply chain networks. ${ }^{5}$ The Revere database provides information on supplier relationships for more than 20,000 publicly traded companies in 2019 , involving over 255,132 such connections. We use each firm's supply-chain relations to infer the firm's supplychain exposure to each country. Revere also provides data on each firm's revenues by country in 2019, which we use to measure each firm's customer exposure by country.

Specifically, Suppliers' exposure equals the weighted average of COVID19 among the foreign countries in which the firm's suppliers are situated, where the weights are the proportion of the firm's pre-pandemic supplies from a country and COVID19 varies weekly as defined above. Similarly, Customers' exposure equals the weighted average of COVID19 among the foreign countries in which the firm sells its products, where the weights are the proportion of the firm's pre-pandemic revenues in a country. We use these two measures to examine whether and the extent to which stock markets "price" a corporation's exposure to the pandemic via its suppliers and customers.

\footnotetext{
${ }^{5}$ For example, Bayerische Motoren Werke AG (BMW) does not report the chemical producer BASF as its supplier. However, from BASF Group's reports, we observe that BMW is a customer of BASF, i.e., BASF is a supplier to BMW. Thus, identifying these types of "reverse relationships" provides a more complete picture of corporate supply chains. For a detailed description of the Revere database, see https://open.factset.com/products/factset-supply-chainrelationships/en-us.
} 
As reported in Table 1, the sample mean and standard deviation of Suppliers' exposure are 0.63 and 0.57 respectively for firms that had some exposure to foreign suppliers. This shows the large cross-firm differences in exposure to COVID-19 through their international supply chains. The message holds for firms' different exposure to COVID-19 through their international customers. Among firms with non-zero revenues from foreign countries, the sample mean and standard deviation of Customers' exposure are 0.47 and 0.5 , respectively

\subsection{CSR}

We retrieve information on firms' CSR performance from the Thomson Reuters ASSET4 ESG database, where ESG stand for Environment, Social, and Governance. Since 2002, Thomson Reuters has collected information from corporate annual reports, stock exchange filings, corporate socially responsible reports, non-profit organizations, the news media, and a variety of other sources. It uses this information to quantify CSR performance for large, publicly-traded firms. When merging the ASSET4 data with our other firm-level data, we obtain CSR performance data in 2018 on 6,135 publicly listed firms in 56 economies.

Thomson Reuters ASSET4 collects over 132 individual indicators of firms' CSR activities and then forms indexes that focus on particular CSR activities. We focus on three indexes linked to each firm's commitment to (1) the environment, including resource use, emissions, and green innovation, (2) non-shareholder stakeholders and social themes, including employee welfare, human rights, and the ethical treatment of customers, suppliers, and the communities in which the firm operates, and (3) operationalizing and implementing CSR activities. We now provide an overview of these three indexes in Appendix Table A1.

The Environmental index is composed of information on three subcomponents, Resource Use, Emission Reduction, and Green Innovation. Resource Use “... reflects a company's performance and capacity to reduce the use of materials, energy or water, and to find more eco- 
efficient solutions by improving supply chain management."'6 (Thomson Reuters, 2018, p. 15) Emission Reduction “... measures a company’s commitment and effectiveness towards reducing environmental emission in the production and operational processes."7 (Thomson Reuters, 2018, p. 15). Green Innovation “... reflects a company's capacity to reduce the environmental costs and burdens for its customers, thereby creating new market opportunities through new environmental technologies and processes or eco-designed products."8 (Thomson Reuters, 2018, p. 15).

The Social index aggregates information on the extent to which firms enhance employee welfare (Workforce), promote human rights (Human Rights), engage in community development (Community), and fulfill their responsibilities to consumers (Product Responsibility). Workforce captures “... a company's effectiveness towards job satisfaction, a healthy and safe workplace, maintaining diversity and equal opportunities, and development opportunities for its workforce."9 (Thomson Reuters, 2018, p. 15) Human Rights measures the degree to which a company respects human rights, e.g., whether a company has a policy to (a) ensure the respect of human rights in

${ }^{6}$ Resource Use aggregates data from 19 indicators that include information on (1) the extent to which companies have policies to improve water efficiency, energy efficiency, and use sustainable packaging; (2) the actual resource use efficiency of companies, including measures such as the ratio of energy consumption to net sales, the proportion of energy generated from renewable energy, and the ratio of water usage to net sales; and (3) the degree to which companies provide detailed data and reports on achieving their own stated initiatives to reduce the use of toxic substances, build environmentally friendly or green buildings, and lessen the degradation of land owned, leased, or managed by the firm or the overall environmental impact of firms in its supply-chain.

${ }^{7}$ Emission Reduction aggregates data from 22 indicators that include information on (1) the extent to which companies have policies or targets to reduce emissions; (2) firms actual emissions of toxic chemical and other pollutants; and (3) the degree to which companies provide detailed data and reports on (a) environmental protection expenditures, (b) their stated initiatives to reduce pollution emissions and their adverse effects on biodiversity, (c) participation in emissions trading initiative and collaboration with environmentally-focused NGOs or other organizations, (d) whether firms have policies to recycle electronic waste, such as computers and air conditioners.

${ }^{8}$ Green Innovation aggregates data from 20 indicators that include information on (1) whether companies (a) report on at least one product line or service that is designed to have positive effects on the environment or which is environmentally labeled and marketed, (b) develop products or technologies for use in the clean, renewable energy (such as wind, solar, hydro and geo-thermal and biomass power), (c) develop products or technologies that are used for water treatment, purification or that improve water use efficiency, (d) develop products and services that improve the energy efficiency or sustainability of buildings, (e) develop new products to reduce noise emissions, (f) show initiatives to produce or promote organic products, and (2) actual corporate investments in green technology, such as the ratio of environmental R\&D expenditures to the revenues, the proportion of energy distributed or produced from renewable energy sources, and average fuel consumption of the firms' fleet of vehicles.

${ }^{9}$ Workforce aggregates data on 29 indicators that include information on (a) the degree of employee satisfaction, whether a company provides flexible working hours and day care services for its employees; (b) the number of occupational-generated diseases, injuries, and fatalities, as well as the amount of company resources to devoted to employee health and safety; (c) diversity and inclusion, such as the percentage of women employees, women managers, employees with disabilities, and whether the company has and implements policies to advance diversity and equal opportunity; and (d) employee training and career development. 
general, (b) ensure the freedom of association of its employees, (c) avoid the use of child labor and forced labor, and (d) use human rights criteria in selecting suppliers. Product Responsibility gauges “... a company's capacity to produce quality goods and services integrating the customer's health and safety, integrity and data privacy."10 (Thomson Reuters, 2018, p. 15). Community measures “... a company's commitment towards being a good citizen, protecting public health and respecting business ethics." 11 (Thomson Reuters, 2018, p. 15). The Community component includes inter alia, measures of whether firms (a) publicize a code of conduct to avoid bribery and corruption, maintain the highest level of general business ethics, improve its good corporate citizenship, and operate as a fair competitor; (b) sell some products or services at a discount in emerging markets, conduct research and development on drugs for diseases in the developing world, and (c) follow international guidelines and provisions such as the OECD Guidelines for Multinational Enterprises, and Extractive Industries Transparency Initiative.

The CSR Strategy index includes information on the degree to which firms organize, operationalize, and implement CSR strategies. It covers whether firms (a) have a CSR sustainability committee, (b) publish CSR/Health\&Safety/Sustainability reports, and whether those reports are published in accordance with the Global Report Initiative Guidelines, (c) have an external audit on CSR related issues, (d) explicitly integrate financial and extra-financial factors in the management discussion and analysis section of the annual reports, and (e) explain how it engages with its stakeholders.

\footnotetext{
${ }^{10}$ Product Responsibility aggregates data on 12 indicators that include information on whether companies (a) have policies to protect customer health and safety, protect customer and general public privacy and integrity, adopt responsible marketing ensuring protection of children, to comply with fair trade rules, regulations, and norms; (b) develop or market products and services that foster specific health and safety benefits for the consumers (such as safe cars), and exclude potentially harmful products from its retail offering (e.g., genetically modified organisms (GMOs), alcohol, tobacco); and (c) monitor the impact of products or services on consumers or the community more generally. ${ }^{11}$ Community aggregates data on 14 indicators that include, inter alia, measures of whether firms (a) publicize a code of conduct to avoid bribery and corruption, maintain the highest level of general business ethics, improve its good corporate citizenship, and operate as a fair competitor; (b) sell some products or services at a discount in emerging markets, conduct research and development on drugs for diseases in the developing world, and (c) follow international guidelines and provisions such as the OECD Guidelines for Multinational Enterprises, and Extractive Industries Transparency Initiative.
} 
We average these three indexes to form an overall measure of CSR performance: CSR Score. We focus most of our analyses on this aggregate index, but also separately examine the three underlying indexes: Environmental, Social, and CSR Strategy.

\subsection{Corporate governance}

Thomson Reuters ASSET4 also empirically characterizes corporate governance systems based on over 100 indicators. Using 2018 values, we use measures of the structure of corporate boards, anti-takeover devices, and executive compensation policies.

We examine five measures of the structure of corporate boards: (1) Board Size Policy equals one if the firm has a policy regarding the size of its board; (2) Board Independence Policy equals one if the firm has a policy regarding the independence of its board; and (3) CEO-Chairman Duality equals one if an individual holds (or has held) both the position of CEO and chair of the board of this company. Some research suggests that board size and independence can shape board integrity and effectiveness, and that separating CEO and board chair responsibilities can influence executive entrenchment.

Regarding firms' anti-takeover devices that can shape executive entrenchment and corporate flexibility, we use a measure of anti-takeover provisions. Antitakeover Devices equals the number of anti-takeover devices in place if there are more than two anti-takeover devices and zero otherwise. The data cover an array of anti-takeover devices, including poison pills, classified boards, blank checks, supermajority votes, dual-class shares, golden parachutes, limited shareholder rights to call for special meetings, cumulative voting rights, pre-emptive rights, company cross shareholdings, confidential voting policies, limited director liability, shareholder approval of significant transactions, fair price provisions, limitations on removal of directors, advance notice for shareholder proposals, written consent requirements, and expanded constituency provisions. Each of these devices can impede takeovers.

For executive compensation, we consider five features of each firm's approach to executive compensation. Executive Compensation Performance Policy equals one if the firm has a 
performance-based compensation policy for the higher-level executives and board members. Executive Compensation LT Objectives equals one if executive and board compensation are partially linked to longer-term objectives, i.e., objectives that are more than two years in the future. Given the extensive body research investigating executive compensation (e.g., Jensen and Murphy 1990; Murphy 2013; Rau 2015; Hermalin and Weisbach 2017), we examine whether these corporate characteristics influence stock price reactions to COVID-19.

\subsection{Ownership structure}

Thomson Reuters provides ownership data for publicly listed firms. It gathers information from a variety of sources, such as regulatory filings, regulatory agencies, company reports, third party vendors, financial publications, and newspapers. Thus, the ownership data includes holdings of institutions and fund portfolios, non-financial companies, individuals, and government agencies. We use each firm's pre-pandemic ownership structure.

Based on the Thomson Reuters data, we classify investors into eight investor types (1) Investment Advisor/Research Firm, referring to mutual funds, investment and asset management companies, such as Vanguard, Fidelity, BlackRock, and the investment bank, asset management, and securities of financial companies, (2) Hedge Fund refers to a hedge fund management firm that is permitted to use aggressive strategies that are unavailable to traditional funds, including selling short, leverage, program trading, swaps, arbitrage and derivatives. Examples of hedge fund investors include Citadel, Two Sigma, and Renaissance Technologies,

Bank/Trust/Insurance/Pension Fund, referring to traditional financial institutions, including commercial banks, trust companies, pension funds, and insurance companies, (4) Individual refers to individual wealthy investors or officers and directors, (5) Corporation that includes holding companies and non-financial corporations, which represent entities that do not invest for purposes of investment management, but rather invest for strategic stakes in companies; (6) Government, referring to government agencies, (7) Sovereign Wealth Fund, and (8) PE/VC that include private equity and venture capital. 
In constructing variables of ownership structure, we focus on blockholders, i.e., investors who own at least $5 \%$ of the total outstanding shares. For each investor type, we construct three measures of ownership. To illustrate, consider the investor type Hedge Fund. For each firm, we calculate the (a) the total percentage of shareholdings by Hedge Fund blockholders, (b) the percentage of shareholdings by the largest Hedge Fund blockholder, and (c) the aggregate percentage of shareholdings by the top five Hedge Fund blockholders. Each of these three measures is constructed using ownership structure measured prior to the pandemic. We construct similar measures for each of the eight investor types.

\subsection{Country characteristics}

Although we include economy-time fixed effects in our core analyses to condition out all time-invariant and time-varying country/economy traits, we also present regression results in which we omit economy-time fixed effects and instead control for specific country characteristics. To capture the overall level and growth rate of economic development, we include GDP per capita (the natural logarithm of GDP per capita) and GDP Growth (the growth rate of GDP) in 2018. We include these measures as economic development shapes the degree to which countries can respond effectively to the pandemic and hence how stock markets respond. Furthermore, we include \%population (aged above 65), which is the percentage of population aged above 65 among the total population of a country. We include this demographic indicator since older people are especially vulnerable to COVID-19. These data are from the World Bank's World Development Indicators for the year of 2018 , the latest year with data.

State power, freedom of expression, and the media can also play a role. We include dummy variables for the country's legal heritage: Common, French, German, Scandinavian or Socialist law. We include these because (1) the popular press in 2020 has suggested that countries with greater state power, relative to the power of individuals, can marshal a more effective response to the pandemic and (2) research argues that civil and socialist legal traditions give much greater power to the state than the common law (Hayek 1960; La Porta et al 1998, 1999; Levine 2005). 
We also examine Voice and Accountability, which measures the ability of individuals in an economy to choose their governments, express their views freely, associate with whom they choose, experience a free press, and hold government officials accountable. Voice and Accountability, which is obtained from the World Bank's World Governance Indicators in 2018, is constructed so that higher values indicate greater individual voice in public affairs and greater press freedom.

\section{Empirical Results}

\subsection{Model specification}

To evaluate how corporate characteristics shape stock price movements in response to the COVID-19 pandemic, we use the following regression model.

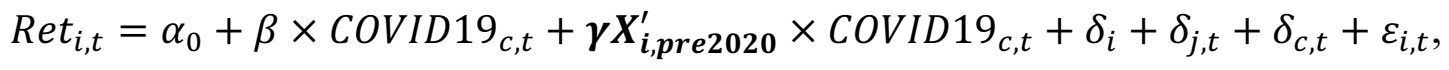

where $i, c, j$, and $t$ index firm, country/economy, industry, and week, respectively. The dependent variable, Ret $_{i, t}$, is the weekly stock return of firm $i$ from the last trading day in week $t$-1 to the last trading day in week $t$. COVID $19_{c, t}$ is the growth rate of the cumulative number of confirmed cases in economy $c$ from in week $t$. Equation (1) includes an array of interactions between pre-pandemic firm characteristics, $\boldsymbol{X}_{\boldsymbol{i}, \boldsymbol{p r e 2 0 2 0}}^{\prime}$, and COVID19, where $\boldsymbol{X}_{\boldsymbol{i} \text {,pre2020 }}^{\prime}$ includes measures of financial conditions, international exposure through suppliers and customers, CSR, governance, and ownership. The inclusion of firm $\left(\delta_{i}\right)$ and industry-time (two-digit SIC industry by week) fixed effects $\left(\delta_{j, t}\right)$ conditions out time-invariant differences across firms and time-varying factors across industries. Our core analyses also include economy-time fixed effects $\left(\delta_{c, t}\right)$ to condition out all time-varying and time-invariant economy traits, such as differences in legal and political systems, policy reactions to the crisis, institutions and cultural norms, demographic, and other crosseconomy traits. In these core analyses, therefore, the linear COVID19 term, which varies at the economy-by-time level, drops from the regressions. In some specifications, we omit the economy- 
time fixed effects, so that we can shed empirical light on how specific country characteristics influence stock price reactions to the pandemic. We estimate Equation (1) using ordinary least squares (OLS), with robust standard errors clustered at the firm level.

As a preliminary benchmark, we simply assess the relationship between stock returns and economies' exposure to the COVID-19 pandemic. That is, we exclude all the interaction terms $\left(\boldsymbol{X}_{i, p r e 2020}^{\prime} \times C O V I D 19\right)$ and the economy-time fixed effects $\left(\delta_{c, t}\right)$ and estimate equation (1). As shown in columns 1 and 2 of Table 2, COVID19 enters negatively and significantly, suggesting that an economy's exposure to the pandemic is strongly and negatively correlated with the stock market performance of firms in that economy. The results hold when including (column 1) or excluding data from the month of January 2020 (column 2). In terms of economic magnitudes, the coefficient estimates from column 1 indicate that if the COVID-19 cases grow at the sample average value (which is about 1.3 of a percentage point) in an economy, then stock prices among firms in that economy tend to fall by about 1.5 percentage points more per week $(=1.3 *-1.16)$. This is material, as it equals $62.8 \%$ of the sample mean value of weekly stock returns over this period (-2.4 percentage points). Accumulating, the estimated impact of this sample average increase in COVID19 over two-months translates into an additional 12 percentage point drop in stock prices. Figure 4 also demonstrates a negative correlation between stock market performance in an economy and the economy's exposure to the COVID19 pandemic.

\subsection{Corporate financial conditions}

We begin by examining four basic financial conditions and report these results in Table 2 . Using the core specification that includes firm, industry-time, and economy-time fixed effects (Column 6), we find that the interactions between COVID19 and Cash and ROA enter positively and significantly, and the interaction with Leverage enters negatively and significantly. These findings are intuitively plausible: as measured by stock price performance, firms with more cash, larger profits, and less debt were more resilient to the pandemic's effect on corporate sales, costs, and financing and liquidity constraints. The estimated impact of these corporate characteristics on 
pandemic-induced stock price changes are robust to (a) excluding economy-time effects and all country traits (column 3) or (b) excluding economy-time effects and instead conditioning on an array of specific country characteristics interacted with COVID19 (columns 4 - 5). It is also worth noting that each of these specific financial conditions enters significantly and robustly when they are included simultaneously. We do not, however, find a robust relationship between firm size and stock price reactions to the pandemic that is independent of corporate cash levels, leverage ratios, and profitability.

To illustrate the economic impacts of Cash, ROA, and Leverage on the sensitivity of stock returns to COVID-19, consider the core specification with economy-time effects. The coefficient estimates from column 6 indicate that a one standard deviation increase in a firm's pre-2020 Cash and $R O A$ would reduce the negative stock price reactions to the pandemic by $0.13(=0.685 * 0.196)$ and $0.2(=1.94 * 0.124)$ percentage points, respectively. And, a one standard deviation increase in a firm's pre-2020 Leverage would intensify the negative stock price reaction to the pandemic by 0.25 percentage points $(=1.2 * 0.204)$, respectively. This is equivalent to $5.6 \%, 10 \%$, and $10.3 \%$ of the sample mean value of weekly stock returns (-2.4). From another perspective, consider (a) two otherwise similar firms in the same industry and economy except that one firm has a leverage ratio at the $25^{\text {th }}$ percentile $(0.103)$ and the other is at the 75 th percentile $(0.395)$, and (b) the average stock price reactions to COVID-19 growth equals -1.16 (column 1 of Table 2). Holding other things constant, the column 6 coefficient estimates imply that the stock price of the high-leverage firm would fall by $27 \%$ more than the other firm $(=(-1.16-1.209 * 0.395) /(-1.16-1.209 * 0.103)$ 1). Using a similar comparison, a low-Cash firm (pre-2020 Cash $=0.039)$ would experience $11 \%$ $(=(-1.16+0.685 * 0.039) /(-1.16+0.685 * 0.203)-1)$ more drop in stock returns than a high-Cash firm (pre-2020 Cash $=0.203)$.

Table 2 also provides estimates on country specific factors. First, coefficient estimates on GDP per capita * COVID19 are positive and statistically significant, suggesting that stock markets in richer economies have weathered the pandemic better than those in poorer economies. Second, coefficient estimates on \%Population (aged above 65) * COVID19 are negative and statistically 
significant, suggesting that stock prices in economies with a larger proportion of the population aged over 65 have experienced much sharper declines. Third, legal tradition is strongly connected to stock price changes during the pandemic. In particular, we discover that firms in economies with French, German, and socialist legal traditions experienced milder stock price declines than those with a common law tradition. To the extent that legal origin captures state vs. individual/court power, these results suggest that markets viewed states with more power as better able to address the public health crisis, mitigating stock price declines. Fourth, we find that the degree of press freedom and individual voice in the political process is not significantly associated with stock performance when conditioning on other country traits.

\subsection{Global supply chain and international customer exposure}

We next examine how a corporations' exposure to COVID-19 through their global supply chains and customer locations affect their stock prices. To the extent that firms' suppliers and customers are situated in countries more affected by COVID-19, we expect those firms to experience greater disruptions to production and sales and hence larger stock price declines. To evaluate how firms' international supply chains and customers locations shape their stock price movements in response to the COVID-19 pandemic, we estimate equation (1) while controlling for Suppliers' exposure and Customers' exposure.

The results reported in Table 3 show that firms experience larger stock price declines when their networks of suppliers and customers are situated in economies more affected by COVID-19. As shown, Suppliers' exposure and Customers' exposure enter negatively and statistically significantly in all columns. The results hold whether including Suppliers' exposure and Customers' exposure separately or simultaneously. Critically, the results are also robust to including (1) the interactions between COVID19 and corporate financial conditions from Table 2 (Firm Size, Leverage, Cash, and ROA) and (2) the full array of firm, industry-time, and economytime fixed (or when instead conditioning on particular country-specific traits). These results 
indicate that stock prices reflect the degree to which firms are differentially exposed to COVID19 through their international connections.

To illustrate the estimated economic magnitudes, consider the specification that includes the most complete set of controls (column 6). The estimates indicate that a one standard deviation increase in a firm's suppliers and customers exposure to COVID-19 would raise the negative stock price reactions to the pandemic by $0.12 \%(=0.212 * 0.573)$ and $0.26 \%(=0.518 * 0.505)$, respectively. This is equivalent to $5 \%$ and $11 \%$ of the sample mean value of weekly stock returns $(-2.4 \%)$. As another illustration, consider (a) two otherwise similar firms except that one firm has Customers' exposure at the $25^{\text {th }}$ percentile $(0.105)$ and the other is at the 75 th percentile $(0.709)$ and $(b)$ the two firms operate in the same foreign countries experience value of COVID19 equal to 1.3 (which is equal to the sample average growth rate). Holding other factors constant, our Table 3 results from column 6 imply that the stock price of the more internationally exposed firm would fall by 3.25 percentage points more than the less exposed firm $(=0.518 *(0.709-0.105) * 1.3 * 8)$ over two months.

\subsection{CSR}

In this subsection, we assess the differential sensitivity of stock price reactions to COVID19 as a function of firms' pre-existing levels of social responsibility. While some research suggests that CSR activities provide private benefits to executives at the expense of shareholders (e.g., Pagano and Volpin 2005; Benabou and Tirole 2010; and Masulis and Reza 2015), other work emphasizes that CSR builds trust with stakeholders that have both long-run efficiency benefits and that make firms more resilient to negative shocks (e.g., Guiso, Sapienza, and Zingales, 2008; Deng, Kang, and Low, 2013; Lins, Servaes, and Tamayo, 2017). Thus, our examination contributes to this debate.

To make this assessment, we use equation (1) and include the interaction between our firmlevel CSR measures and COVID19. In particular, we separately examine the interaction term using the overall CSR index (CSR score) and each of its three sub-indexes: Environmental, Social, and 
CSR Strategy. In our core regressions presented in the even numbered columns in Table 4, we condition on each of the firm-specific financial conditions interacted with COVID19, as well as firm, industry-time, and economy-time fixed effects. For completeness, we report the results that exclude economy-time effects and instead include the specific country traits discussed above in the odd numbered columns in Table 4.

The results presented in Table 4 suggest that the stock prices of corporations with greater pre-2020 scores of CSR performance fall less in response to COVID-19. This result emerges when examining the overall index, CSR score, and when examining each of the sub-indexes: Environmental, Social, and CSR Strategy. In particular, the interaction between COVID19 and each of these four CSR measures enters positively and significantly. The results are consistent with the view that CSR investments strengthen the informal ties between a firm and its workers, suppliers, customers, and other stakeholders, enabling the firm to more effectively and efficiently work with those stakeholders, and enhance the firm's likelihood of survival and future success.

The estimated coefficients suggest that corporate CSR differences materially influence stock return reactions to COVID-19. Consider, for example, the overall index, CSR score, and our core specification (from column 2). Consider two otherwise similar firms in the same industry and economy. One has a pre-2020 CSR score at the $25^{\text {th }}$ percentile and the other is at the 75 th percentile. Our estimates suggest that the average weekly stock returns of the high-CSR score firm would decline by $0.23(=0.548 * 1.3 *(0.674-0.343))$ percentage points less than the low-CSR score firm in response to the average growth of COVID19 cases (1.3). Cumulating, the stock price of the high CSR score firm would be 2 percentage points higher two months after the outbreak of the pandemic. Thus, the stock price reaction to COVID19 for the high-CSR score firm would be $19 \%$ less than the low-CSR score firm $(=(-1.16+0.548 * 0.674) /(-1.16+0.548 * 0.343)-1)$ based on the average stock price reactions in column 1 of Table 2. 


\subsection{Corporate governance}

We next examine measures of corporate governance. To the extent that the pandemic induces stock markets to put a premium on corporate flexibility, including the ability to be purchased by another firm or to change leadership, stronger antitakeover devices and greater executive entrenchment might induce larger stock price declines. In addition, theories of tunneling suggest that periods of great uncertainty and tumult might create opportunities for insiders to extract private rents at the expense of other stakeholders (e.g., Johnson et al. 2000). This view predicts that firms that impede the takeovers and grant greater authority to executives and insiders will suffer greater stock price declines during the spread of COVID-19. To assess these predictions, we include the interactions of COVID19 with several corporate governance measures of board structure, anti-takeover devices, and executive compensation policies.

Results in Table 5 indicate that firms with more entrenched executives tend to experience greater stock price declines during the COVID-19 crisis. Consider the results on Antitakeover Devices which tend to impede takeovers and protect executives. As shown in columns 1 and 2, the interaction between Antitakeover Devices and COVID19 enters negatively and significantly, indicating that stock prices of firms with more anti-takeover provisions fall faster in response to COVID-19 than firms with fewer anti-takeover provisions. These results are consistent with the view that stock markets viewed executive entrenchment negatively in assessing corporation resilience to the crisis.

To illustrate the estimated economic importance of executive entrenchment on stock price reactions to the pandemic, consider the coefficient estimates on the Antitakeover DevicesCOVID19 interaction term. Consider two otherwise similar firms in an industry. One has pre-2020 Antitakeover Devices at the $25^{\text {th }}$ percentile (1) of the sample distribution of Antitakeover Devices and the other firm is at the 75th percentile (6). The coefficient estimates in column 2 of Table 5 suggest that the average weekly stock return of the high-Antitakeover Devices firm would decline by $0.25(=-0.038 * 1.29 *(6-1))$ percentage points more than the otherwise similar low-Antitakeover Devices firm. That is, the high-Antitakeover Devices firm would experience stock price declines 
of $24 \%$ more than the low- Antitakeover Devices firm $(=(-1.16-0.038 * 6) /(-1.16+0.038 * 1)-1)$ based on the average stock price reactions in column 1 of Table 2).

Table 5 provides results on two other features of corporate governance: the structure of the board of directors and executive compensation policies. We examine several features of the board emphasized in the literature on corporate governance: the size of the board (Board Size Policy), the degree of independence of board members from the executive (Board Independence Policy), and whether the positions of CEO and Board Chair are split (CEO-Chairman Duality). We also examine two features of executive compensation: whether the company has pay-for-performance compensation policy (Executive Compensation Performance Policy) and whether pay-forperformance is connected to long-run objectives (Executive Compensation LT Objectives. As shown, none of the features of board structure or executive compensation enters significantly. There is no evidence that corporate stock price reactions to COVID-19 vary systematically with board structure or executive compensations systems. ${ }^{12}$

\subsection{Ownership structure}

Finally, we examine corporate ownership. In particular, we examine whether stock price sensitivity to COVID-19 is associated with the identity of a firm's blockholders (i.e., Investment Advisor/Research Firm, Hedge Fund, Bank/Trust/Insurance/Pension Fund, Individual Investors, Corporation, Government, Sovereign Wealth Fund, and PE/VC. The stock prices of firms owned by different types of investors might react differently to the pandemic. For example, hedge funds might be more focused on pursuing short-run stock performance and engaging in high-frequency trading than other blockholders. As a result, they might be more likely to sell shares quickly in response to news about COVID-19, generating downward pressure on the prices of companies in

\footnotetext{
12 In Table 5, we report the results on board structure (columns 3 and 4) while including the three measures of board structure simultaneously. Similarly, we report the results on executive compensation (columns 5 and 6) while including the two indicators of executive compensation simultaneously. In Appendix Table A2, we examine each of the three board measures and two compensation measures independently. Each of these five indicators also enters insignificantly when examined independently.
} 
which they are large shareholders. ${ }^{13}$ As another example, if a firm has a large, strategic corporate investor as a major block shareholder, then the market might expect this blockholder to provide support for this firm during the crisis, dampening the impact of COVID-19 on the firm. Empirically we evaluate these views of ownership structure by adding the interactions of COVID19 with each of the eight ownership measures to equation 1.

Results reported in Table 6 suggest that (a) the stock prices of firms owned by hedge funds perform worse during the COVID-19 crisis, and (b) the stock prices of firms owned by nonfinancial corporations perform better. As shown, Hedge Fund * COVID19 enters negatively and significantly, while Corporation * COVID19 enters positively and significantly in all specifications. Other investor types, such as Investment Advisor/Research Firm, Bank/Trust/Insurance/Pension Fund, or PE/VC do not exhibit any significant relationship with corporate resilience to the pandemic. The results hold when measuring each type of ownership using the percentage of shareholdings among all blockholders, the largest blockholder, and the top five blockholders. These findings are consistent with the view that hedge funds sell their shares rapidly in response to new information about COVID-19 cases or to meet liquidity needs (e.g., Stein 2009; Khandani and Lo 2011), putting downward pressure on prices, whereas owners with long-run, strategic commitments to firms (such as large corporations) mute the impact of the pandemic on stock prices. To illustrate the economic magnitude, we focus on Hedge Fund and Corporation, using the coefficient estimates from column 2 of Table 6. Consider two otherwise similar firms in an industry, and one has a pre-existing Corporation ownership equal to one standard deviation equal to 0.228 , the other equal to 0 . Our estimates suggest that the average stock return of the high-Corporation-owned firm would decline by $0.19(=0.651 * 1.29 * 0.228)$ percentage points less per week in response to the average economy-wide exposure to the COVID19 shock (1.29) than the otherwise similar firm. That is, compared to the firm without any

\footnotetext{
${ }^{13}$ In 2015, Laurence Fink, the chairman and CEO of BlackRock, the world's largest institutional investor, argued that "...response to the acute pressure, growing with every quarter, for companies to meet short-term financial goals at the expense of building long-term value. This pressure originates from a number of sources-the proliferation of activist shareholders seeking immediate returns, ...”.
} 
pre-existing Corporation ownership, the stock price of the firm with Corporation ownership equal to one standard deviation ( 0.228$)$ would drop less by about 1.5 percentage points two months after the spread of COVID-19. In contrast, compared to the firm with zero pre-existing Hedge Fund block ownership, the stock price of the firm with Hedge Fund ownership (equal to one standard deviation: 0.047 ) would decline by more than 1.2 percentage points more over two months in response to an average economy-wide exposure to COVID-19.

\subsection{Corporate characteristics: Simultaneous analyses}

In Table 7, we simultaneously examine all five pre-2020 corporate characteristics: corporate financial conditions, international supply chain and customer exposure to the pandemic, corporate social responsibility, corporate governance systems, and ownership structure. Using equation 1 and core specification, we add the five corporate characteristics in a stepwise manner, ultimately including all of the corporate traits simultaneously in column (3). Since many firm traits might be correlated, we include them simultaneously to assess the independent connection between stock price reactions to COVID-19 and each of these corporate characteristics. In particular, besides conditioning on firm, industry-by-time, and economy-by-time fixed effects, we include the interactions between COVID19 and (1) the four financial condition indicators (Firm size, Leverage, Cash, and ROA), (2) the measures of each firms exposure to the pandemic through international supply chain and customers (Suppliers' exposure and Customers' exposure), (3) each firm's measure of overall socially responsible activities (CSR score), (4) the extent to which a firm's corporate governance system contains antitakeover devices (Antitakeover Devices), which help entrench executives, and (5) the firm's ownership structure, in particular the extent to which a hedge fund or other corporation owns the firm (Hedge Fund and Corporation, respectively).

As shown in Table 7, each of the indicators enters statistically significantly, with the same sign and similar estimated coefficient as the earlier findings (Tables $2-6$ ). The consistency of estimated coefficient on these five corporate characteristics across various specifications highlights the independent connection between each of these corporate characteristics and the 
sensitivity of stock prices to the COVID-19 pandemic. This suggests that these indicators of firm traits indeed capture different aspects of corporate resilience, not the same factor being proxied by different covariates.

\section{Conclusion}

Which characteristics shape corporate immunity to the COVID-19 pandemic? To shed empirical light on this question, we evaluated the connection between corporate characteristics and stock price reactions to COVID-19 using data on over 6,000 firms across 56 economies during the first quarter of 2020. While the economic turmoil triggered by COVID-19 is different from past crises, we consider corporate characteristics that have been the focus of research for decades. In particular, we examine stock price reactions to COVID-19 cases as functions of five pre-2020 firm traits: (1) financial conditions, such as cash holdings, leverage, and profitability, (2) international supply chain and customer locations, which provides information on each firm's exposure to COVID-19 through its international connections, (3) CSR activities, (4) corporate governance systems, such as antitakeover mechanisms, board structures, and executive compensation policies, and (5) ownership structures, such as the identities of firms' large blockholders.

We find the following. First, firms with stronger pre-2020 financial conditions-more cash, less debt, and larger profits - experienced better stock price reactions to COVID-19 than otherwise similar firms. Second, firms' international exposure to COVID-19 mattered. The pandemic-induced drop in stock prices was larger among firms that were more exposed to the COVID-19 pandemic through their international supply chains and customer locations. Third, firms stronger CSR policies and activities prior to the pandemic experienced superior stock price performance in response to COVID-19. These findings are consistent with the view that CSR builds trust with stakeholders, which makes workers, suppliers, and customers more amenable to making adjustments to support the business in times of duress. Fourth, firms with less entrenched executives performed better in response to COVID-19 cases. These findings are consistent with the view that in assessing responses to the pandemic, markets positively priced flexibility, 
including mergers, acquisitions, and leadership changes, and governance systems that limit tunneling. Fifth, the identity of firms' large owners are strongly associated with stock price reactions to COVID-19 cases: (a) the stock prices of firms owned by hedge funds perform worse, and (b) the stock prices of firms owned by non-financial corporations perform better. These findings are consistent with the view that hedge funds sell their shares rapidly in response to negative information about COVID-19 cases, intensifying downward pressure on prices, while owners with long-run, strategic commitments to firms (including large corporations), tend to dampen the adverse impact of the pandemic on stock prices. 


\section{References}

Acemoglu, Daron, Vasco M. Carvalho, Asuman Ozdaglar, and Alireza Tahbaz-Salehi, 2012, The network origins of aggregate fluctuations, Econometrica 80, 1977-2016.

Acemoglu, Daron, Asuman Ozdaglar, and Alireza Tahbaz-Salehi, 2017, Microeconomic origins of macroeconomic tail risks, American Economic Review 107, 54-108.

Aghion, Philippe, Nicholas Bloom, Brian Lucking, Raffaella Sadun, and John Van Reenen, 2017, Turbulence, firm decentralization and growth in bad times, National Bureau of Economic Research Working Paper Series No. 23354.

Albuquerque, Rui, Yrjö Koskinen, and Chendi Zhang, 2019, Corporate social responsibility and firm risk: Theory and empirical evidence, Management Science 65, 4451-4469.

Arrow, Kenneth, 1972, Gifts and exchanges, Philosophy and Public Affairs 343-362.

Bates, Thomas W., Kathleen M. Kahle, and René M. Stulz, 2009, Why do U.S. firms hold so much more cash than they used to?, Journal of Finance 64, 1985-2021.

Bebchuk, Lucian, Alma Cohen, and Allen Ferrell, 2009, What matters in corporate governance?, Review of Financial Studies 22, 783-827.

Beltratti, Andrea, and René M. Stulz, 2012, The credit crisis around the globe: Why did some banks perform better?, Journal of Financial Economics 105, 1-17.

Bénabou, Roland, and Jean Tirole, 2010, Individual and corporate social responsibility, Economica 77, 1-19.

Bernanke, Ben, 2020, Ben Bernanke on COVID-19 downturn, Marketplace, Available at https://www.marketplace.org/2020/03/23/former-fed-chair-bernanke-covid19-downturn/.

Claessens, Stijn, Simeon Djankov, and Larry H. P. Lang, 2000, The separation of ownership and control in East Asian Corporations, Journal of Financial Economics 58, 81-112.

Coase, R. H., 1937, The nature of the firm, Economica 4, 386-405.

Cremers, K.J. Martijn, and Vinay B. Nair, 2005, Governance mechanisms and equity prices, Journal of Finance 60, 2859-2894.

Deng, Xin, Jun-koo Kang, and Buen Sin Low, 2013, Corporate social responsibility and stakeholder value maximization: Evidence from mergers, Journal of Financial Economics 110, 87-109.

Djankov, Simeon, Rafael La Porta, Florencio Lopez-de-Silanes, and Andrei Shleifer, 2008, The law and economics of self-dealing, Journal of Financial Economics 88, 430-465.

Djankov, Simeon, Caralee McLiesh, Tatiana Nenova, and Andrei Shleifer, 2003, Who owns the media?, Journal of Law and Economics 46, 341-382. 
Dong, Ensheng, Hongru Du, and Lauren Gardner, 2020, An interactive web-based dashboard to track COVID-19 in real time, The Lancet Infectious Diseases.

Fahlenbrach, Rüdiger, and René M. Stulz, 2011, Bank CEO incentives and the credit crisis, Journal of Financial Economics 99, 11-26.

Giroud, Xavier, and Holger M. Mueller, 2011, Corporate governance, product market competition, and equity prices, Journal of Finance 66, 563-600.

Giroud, Xavier, and Holger M. Mueller, 2017, Firm leverage, consumer demand, and employment losses during the Great Recession, Quarterly Journal of Economics 132, 271-316.

Gompers, Paul, Joy Ishii, and Andrew Metrick, 2003, Corporate governance and equity prices, Quarterly Journal of Economics 118, 107-156.

Guiso, Luigi, Paola Sapienza, and Luigi Zingales, 2004, The role of social capital in financial development, American Economic Review 94, 526-556.

Guiso, Luigi, Paola Sapienza, and Luigi Zingales, 2008, Trusting the stock market, Journal of Finance 63, 2557-2600.

Guo, Lixiong, and Ronald W. Masulis, 2015, Board structure and monitoring: New evidence from CEO turnovers, Review of Financial Studies 28, 2770-2811.

Hanselaar, Rogier M., René M. Stulz, and Mathijs A. Van Dijk, 2019, Do firms issue more equity when markets become more liquid?, Journal of Financial Economics 133, 64-82.

Harford, Jarrad, 1999, Corporate cash reserves and acquisitions, Journal of Finance 54, 1969-1997.

Harford, Jarrad, Sattar A. Mansi, and William F. Maxwell, 2008, Corporate governance and firm cash holdings in the US, Journal of Financial Economics 87, 535-555.

Hayek, Friedrich A., 1960. The Constitution of Liberty (University of Chicago Press).

Hermalin, Benjamin E., and Michael S. Weisbach, 1998, Endogenously chosen boards of directors and their monitoring of the CEO, American Economic Review 96-118.

Hermalin, Benjamin E., and Michael S. Weisbach, 2003, Boards of directors as an endogenously determined institution: A survey of the economic literature, Economic Policy Review Federal Reserve Bank of New York 9, 7-26.

Hermalin, Benjamin E., and Michael S. Weisbach, 2017. The Handbook of the Economics of Corporate Governance (Netherlands: North Holland).

Hertzel, Michael G., Zhi Li, Micah S. Officer, and Kimberly J. Rodgers, 2008, Inter-firm linkages and the wealth effects of financial distress along the supply chain, Journal of Financial Economics 87, 374-387. 
Jensen, Michael C., 1988, Takeovers: Their causes and consequences, Journal of Economic Perspectives 2, 21-48.

Jensen, Michael C., and William H. Meckling, 1976, Theory of the firm: Managerial behavior, agency costs and ownership structure, Journal of Financial Economics 3, 305-360.

Jensen, Michael C., and Kevin J. Murphy, 1990, Performance pay and top-management incentives, Journal of Political Economy 98, 225-264.

Jensen, Michael C., and Richard S. Ruback, 1983, The market for corporate control: The scientific evidence, Journal of Financial Economics 11, 5-50.

Johnson, Simon, Rafael La Porta, Florencio Lopez-de-Silanes, and Andrei Shleifer, 2000, Tunneling, American Economic Review 90, 22-27.

Kahle, Kathleen M., and René M. Stulz, 2013, Access to capital, investment, and the financial crisis, Journal of Financial Economics 110, 280-299.

Khandani, Amir E., and Andrew W. Lo, 2011, What happened to the quants in August 2007 ? Evidence from factors and transactions data, Journal of Financial Markets 14, 1-46.

Knack, Stephen, and Philip Keefer, 1997, Does social capital gave an economic payoff? A crosscountry investigation, Quarterly Journal of Economics 112, 1251-1288.

La Porta, Rafael, Florencio Lopez-de-Silanes, and Andrei Shleifer, 1999, Corporate ownership around the world, Journal of Finance 54, 471-517.

La Porta, Rafael, Florencio Lopez-de-Silanes, and Andrei Shleifer, 2008, The economic consequences of legal origins, Journal of Economic Literature 46, 285-332.

La Porta, Rafael, Florencio Lopez-de-Silanes, Andrei Shleifer, and Robert W. Vishny, 1998, Law and finance, Journal of Political Economy 106, 1113-1155.

La Porta, Rafael, Florencio Lopez-de-Silanes, Andrei Shleifer, and Robert W. Vishny, 1999, The quality of government, Journal of Law, Economics, and Organization 15, 222-279.

La Porta, Rafael, Florencio Lopez-de-Silanes, Andrei Shleifer, and Robert W. Vishny, 2000, Investor protection and corporate governance, Journal of Financial Economics 58, 3-27.

La Porta, Rafael, Andrei Shleifer, and Robert W. Vishny, 1997, Trust in large organizations, American Economic Review 87, 333-338.

Laeven, Luc, and Ross Levine, 2008, Complex ownership structures and corporate valuations, Review of Financial Studies 21, 579-604.

Levine, Ross, 2005, Law, endowments and property rights, Journal of Economic Perspectives 19, 61-88. 
Lin, Chen, Yue Ma, Paul Malatesta, and Yuhai Xuan, 2011, Ownership structure and the cost of corporate borrowing, Journal of Financial Economics 100, 1-23.

Lins, Karl V., Henri Servaes, and Ane Tamayo, 2017, Social capital, trust, and firm performance: The value of corporate social responsibility during the financial crisis, Journal of Finance $72,1785-1824$.

Lo, Andrew W., 2008. Hedge Funds: An Analytic Perspective (Princeton University Press).

Long, John B., and Charles I. Plosser, 1983, Real business cycles, Journal of Political Economy 91, 39-69.

Masulis, Ronald W., and Syed Walid Reza, 2015, Agency problems of corporate philanthropy, Review of Financial Studies 28, 592-636.

Morck, Randall, Andrei Shleifer, and Robert W. Vishny, 1988, Management ownership and market valuation: An empirical analysis, Journal of Financial Economics 20, 293-315.

Morck, Randall, Daniel Wolfenzon, and Bernard Yeung, 2005, Corporate governance, economic entrenchment, and growth, Journal of Economic Literature 43, 655-720.

Murphy, Kevin J., 2013, Executive compensation: Where we are, and how we got there, in Milton Harris, and René Stulz, eds.: Handbook of the Economics of Finance (Elsevier B.V) 211356.

Pagano, Marco, and Paolo Volpin, 2005, The political economy of corporate governance, American Economic Review 95, 1005-1030.

Pinkowitz, Lee, René M. Stulz, and Rohan Williamson, 2016, Do U.S. firms hold more cash than foreign firms do?, Review of Financial Studies 29, 309-348.

Putnam, Robert D., 1993. Making democracy work: Civic traditions in modern Italy (Princeton University Press, Princeton, N.J.).

Rau, Raghavendra, 2015, Executive Compensation, Foundations and Trends in Finance 10, 181362.

Reinhart, Carmen M., 2020, This time truly is different, Project Syndicate, Available at https://www.project-syndicate.org/commentary/covid19-crisis-has-no-economicprecedent-by-carmen-reinhart-2020-03.

Reinhart, Carmen M., and Kenneth S. Rogoff, 2009. This Time is Different: Eight Centuries of Financial Folly (Princeton University Press).

Schwartz-Ziv, Miriam, and Michael S. Weisbach, 2013, What do boards really do? Evidence from minutes of board meetings, Journal of Financial Economics 108, 349-366. 
Shleifer, Andrei, and Robert W. Vishny, 1997, A survey of corporate governance, Journal of Finance 52, 737-783.

Stein, Jeremy C., 2009, Presidential address: Sophisticated investors and market efficiency, Journal of Finance 64, 1517-1548.

Thomson Reuters, 2018, Thomson Reuters ESG Scores, Available at https://www.refinitiv.com/content/dam/marketing/en_us/documents/methodology/esgscores-methodology.pdf.

Tirole, Jean, 2001, Corporate governance, Econometrica 69, 1-35. 


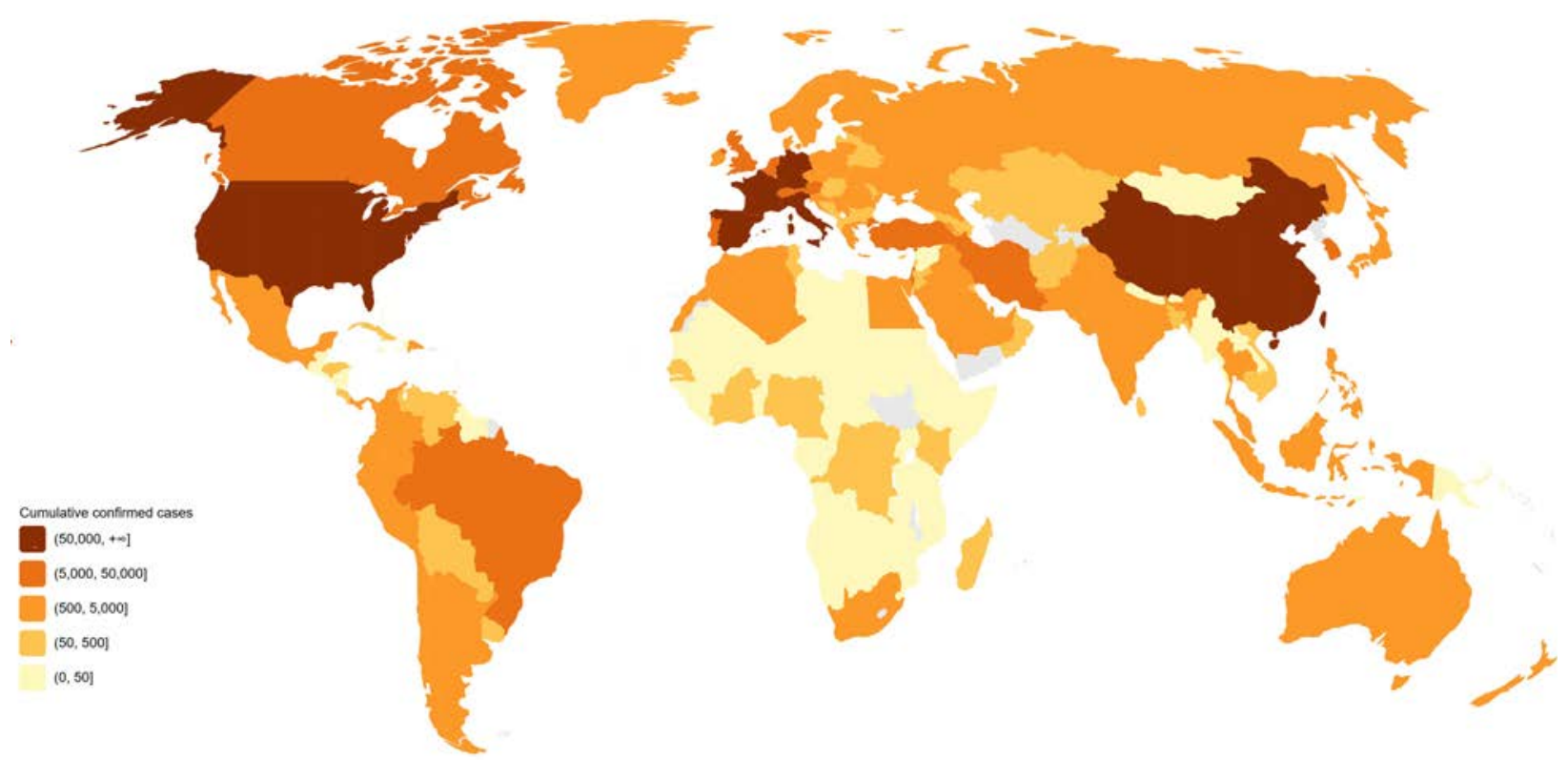

\section{Figure 1. Cumulative COVID19 Cases}

This figure shows the cumulative COVID-19 confirmed cases around the world as of 2020 March $31^{\text {st }}$. Using data provided by the Center for Systems Science and Engineering (CSSE) at Johns Hopkins University, we classify economies into five groups based on the confirmed cases, namely $(0,50],(50,500],(500,5,000],(5,000,50,000]$, and above 50,000. Darker colors indicate a larger number of confirmed cases.

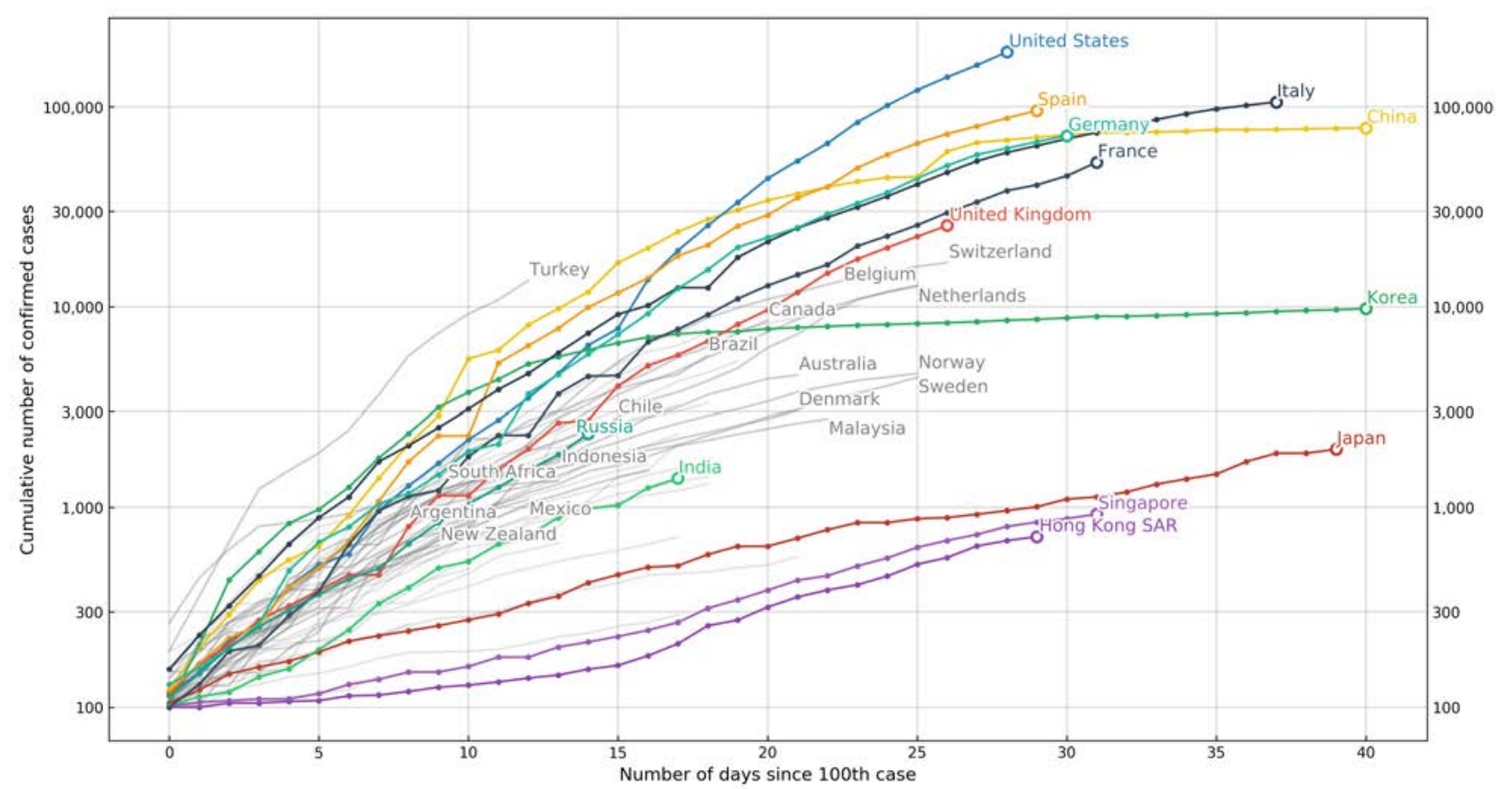

Figure 2. Growth Rates of COVID19 cases by Economy

This figure demonstrates the growth rate of the number of COVID19 cases in each of the 56 sample economies. The $\mathrm{x}$-axis denotes the number of days since the $100^{\text {th }}$ confirmed cases in an economy. The $\mathrm{y}$-axis denotes the cumulative number of confirmed cases in a given economy. (Source: Johns Hopkins University, CSSE) 


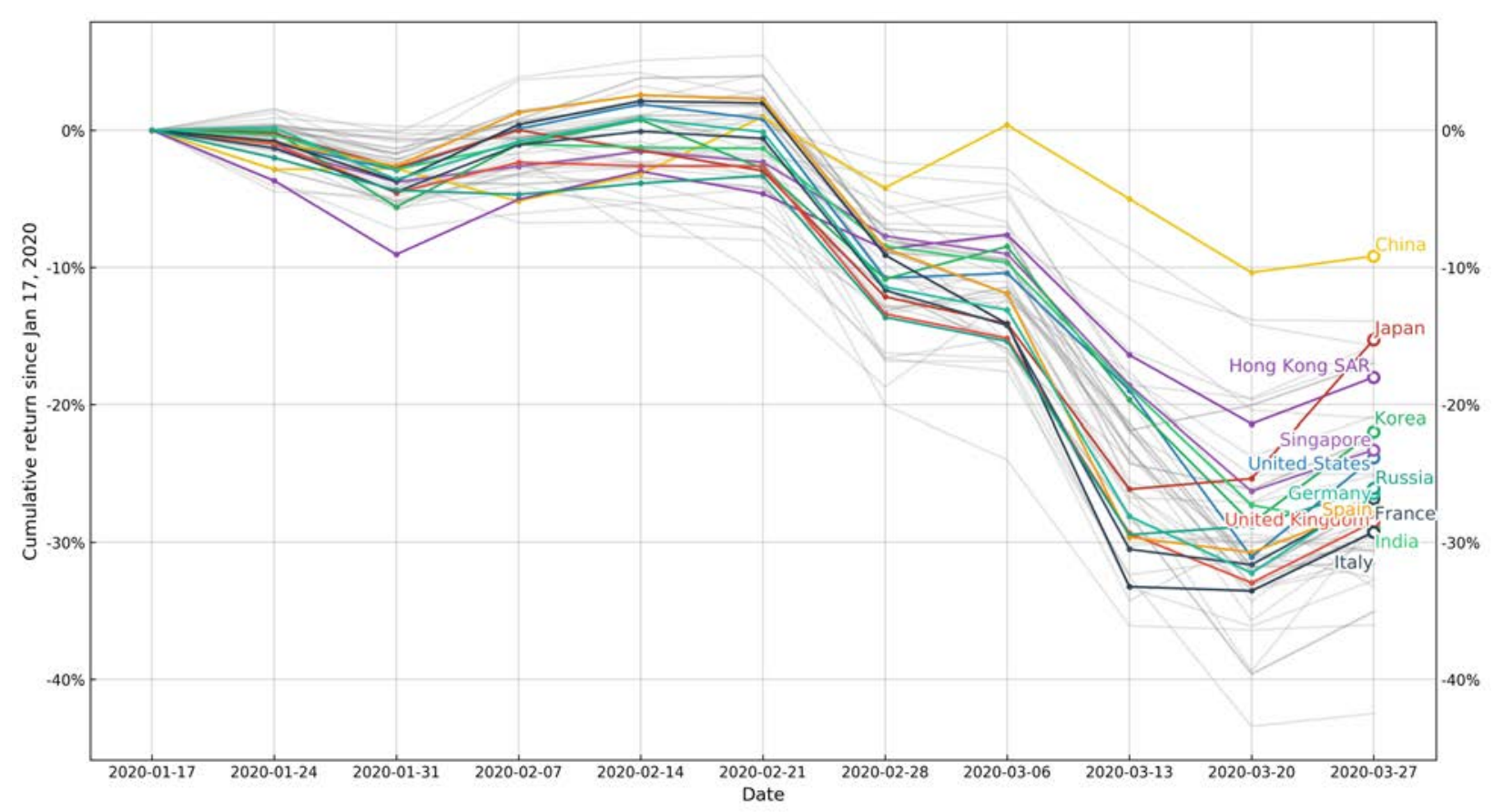

Figure 3. Stock Market Returns since the Spread of COVID-19

This figure plots the cumulative stock market returns since mid-January of 2020 for each of the 56 sample economies. For each economy, we calculate the cumulative return using the dividend-adjusted Global Equity Index provided by Thomson Reuters.

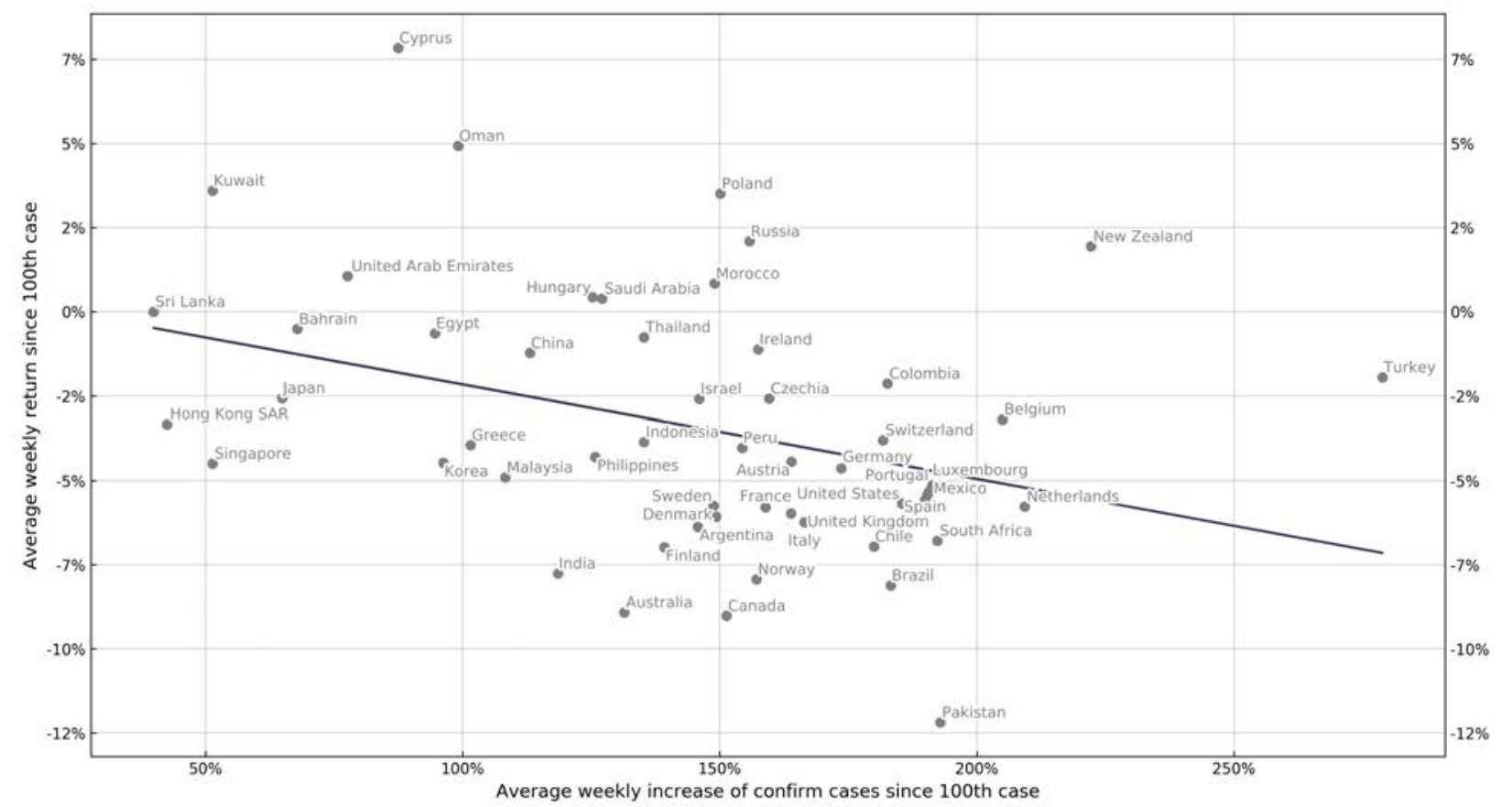

\section{Figure 4. \#COVID19 Confirmed Cases and Stock Return}

This figure presents the cross-sectional relation between average weekly stock returns across firms in an economy and the growth rate of COVID-19 cases. Each spot represents an economy. The x-axis denotes the average weekly growth rate of COVID-19 cases in an economy since the number of confirmed cases in the economy exceeded 100. The yaxis represents the weekly stock returns, averaged across the sample firms in an economy. 


\section{Table 1 Summary Statistics}

This table presents the summary statistics of the key variables used in our analyses. The sample includes global publicly listed firms covered in the Thomson Reuters Worldscope and ASSET4 ESG database. Firm- and economy-level statistics are calculated using 6,135 firms in 56 economies.

\begin{tabular}{|c|c|c|c|c|c|c|c|c|}
\hline & $\mathrm{N}$ & Mean & Std. Dev. & p10 & p25 & $\mathrm{p} 50$ & $\mathrm{p} 75$ & p90 \\
\hline Weekly stock return & 79,739 & -2.409 & 9.183 & -14.476 & -6.257 & -0.987 & 2.090 & 6.424 \\
\hline COVID19 & 728 & 0.574 & 0.871 & 0 & 0 & 0 & 1.099 & 1.792 \\
\hline COVID19 (exposed economy-week) & 323 & 1.295 & 0.881 & 0.262 & 0.693 & 1.197 & 1.724 & 2.427 \\
\hline \multicolumn{9}{|l|}{ Firm characteristics } \\
\hline Firm size & 79,739 & 14.924 & 1.684 & 12.787 & 13.830 & 14.916 & 16.030 & 17.089 \\
\hline Leverage & 79,739 & 0.268 & 0.204 & 0.001 & 0.103 & 0.253 & 0.395 & 0.540 \\
\hline Cash & 79,739 & 0.164 & 0.196 & 0.014 & 0.039 & 0.095 & 0.203 & 0.425 \\
\hline ROA & 79,739 & 0.030 & 0.124 & -0.054 & 0.012 & 0.041 & 0.079 & 0.132 \\
\hline Suppliers' exposure & 59,262 & 0.360 & 0.533 & 0 & 0 & 0.103 & 0.575 & 1.104 \\
\hline Customers' exposure & 64,684 & 0.246 & 0.434 & 0 & 0 & 0.009 & 0.322 & 0.855 \\
\hline Suppliers' exposure (exposed firm) & 34,068 & 0.627 & 0.573 & 0.080 & 0.194 & 0.477 & 0.922 & 1.365 \\
\hline Customers' exposure (exposed firm) & 33,662 & 0.473 & 0.505 & 0.031 & 0.105 & 0.300 & 0.709 & 1.174 \\
\hline CSR score & 79,739 & 0.508 & 0.200 & 0.258 & 0.343 & 0.491 & 0.674 & 0.790 \\
\hline Environmental & 79,739 & 0.508 & 0.223 & 0.220 & 0.322 & 0.497 & 0.684 & 0.822 \\
\hline Social & 79,739 & 0.508 & 0.212 & 0.226 & 0.344 & 0.509 & 0.667 & 0.799 \\
\hline CSR Strategy & 79,739 & 0.508 & 0.270 & 0.151 & 0.354 & 0.394 & 0.769 & 0.901 \\
\hline Antitakeover Devices & 79,726 & 3.517 & 2.898 & 0 & 1 & 3 & 6 & 8 \\
\hline Board Size Policy & 78,517 & 0.777 & 0.416 & 0 & 1 & 1 & 1 & 1 \\
\hline Board Independence Policy & 78,517 & 0.681 & 0.466 & 0 & 0 & 1 & 1 & 1 \\
\hline CEO-Chairman Duality & 78,517 & 0.334 & 0.472 & 0 & 0 & 0 & 1 & 1 \\
\hline Executive Compensation Performance Policy & 78,517 & 0.869 & 0.337 & 0 & 1 & 1 & 1 & 1 \\
\hline Executive Compensation LT Objectives & 78,517 & 0.097 & 0.296 & 0 & 0 & 0 & 0 & 0 \\
\hline Investment Advisor/Research firm & 79,739 & 0.139 & 0.151 & 0 & 0 & 0.089 & 0.244 & 0.361 \\
\hline Hedge Fund & 79,739 & 0.012 & 0.047 & 0 & 0 & 0 & 0 & 0 \\
\hline Bank/Trust/Insurance/Pension Fund & 79,739 & 0.009 & 0.036 & 0 & 0 & 0 & 0 & 0 \\
\hline Individual & 79,739 & 0.043 & 0.122 & 0 & 0 & 0 & 0 & 0.148 \\
\hline
\end{tabular}




\begin{tabular}{lcccccccc}
\hline & $\mathrm{N}$ & Mean & Std. Dev. & $\mathrm{p} 10$ & $\mathrm{p} 25$ & $\mathrm{p} 50$ & $\mathrm{p} 75$ & $\mathrm{p} 90$ \\
\hline Corporation & 79,739 & 0.136 & 0.228 & 0 & 0 & 0 & 0.198 & 0.534 \\
Government & 79,739 & 0.012 & 0.076 & 0 & 0 & 0 & 0 & 0 \\
Sovereign Wealth Fund & 79,739 & 0.007 & 0.044 & 0 & 0 & 0 & 0 & 0 \\
PE/VC & 79,739 & 0.009 & 0.056 & 0 & 0 & 0 & 0 & 0 \\
\hline Economy Traits & & & & & & & \\
\hline GDP per capita & 56 & 9.822 & 1.200 & 8.014 & 9.085 & 10.076 & 10.781 & 10.972 \\
GDP growth & 56 & 0.030 & 0.019 & 0.012 & 0.018 & 0.027 & 0.040 & 0.062 \\
\%population(aged above 65) & 56 & 12.822 & 6.761 & 2.550 & 6.842 & 13.792 & 18.895 & 21.462 \\
Legor=English & 56 & 0.375 & 0.489 & 0 & 0 & 0 & 1 \\
Legor=French & 56 & 0.375 & 0.489 & 0 & 0 & 0 & 1 \\
Legor=German & 56 & 0.161 & 0.371 & 0 & 0 & 0 & 0 \\
Legor=Scandinavian & 56 & 0.071 & 0.260 & 0 & 0 & 0 & 0 \\
Legor=Socialist & 56 & 0.018 & 0.134 & 0 & 0 & 0 & 0 \\
\hline
\end{tabular}




\section{Table 2 Corporate financial conditions and stock returns in response to the COVID-19 pandemic}

This table shows how (a) economy characteristics and (b) firm financial conditions shape stock price movements in response to the COVID-19 pandemic during the first quarter of 2020. The dependent variable is weekly stock return of each firm in a week in all columns. The key explanatory variable is COVID19 and its interactions with an array of economy and firm characteristics. COVID19 is the weekly growth rate of the number of confirmed COVID-19 cases in an economy. In particular, For economy $c$ in week $t$, COVID19 $=\log (1+\#$ confirmed cases in week $t)-$ $\log (1+\#$ confirmed cases in week $t$-1). Economy characteristics include GDP Per Capita, GDP Growth, \%population(aged above 65), and Legal Origin, measured prior to 2020. GDP Per Capita is the natural logarithm of GDP per capita of an economy; GDP Growth is the annual growth rate of GDP of an economy; \%population (aged above 65) is percentage of population aged above 65 among the total population of an economy; Legal Origin denotes a set of indicators equal to one if an economy's legal origin is French, German, Scandinavian, or Socialist. The omitted group of legal origin is the English common law. We measure firm financial conditions using Firm Size, Leverage, Cash, and ROA. For each firm, Firm Size is the natural logarithm of the book value of total assets; Leverage is total debt divided by total assets; Cash is cash and short-term investments divided by total assets; $R O A$ is net income divided by total assets. Appendix Table A1 provides detailed variable definition. We include firm, industry (two-digit SIC) by week, and/or economy by week fixed effects. Robust standard errors clustered at the firm level are reported in parentheses. ${ }^{* * *}, * *, *$ denote significance levels at $1 \%, 5 \%$ and $10 \%$ respectively.

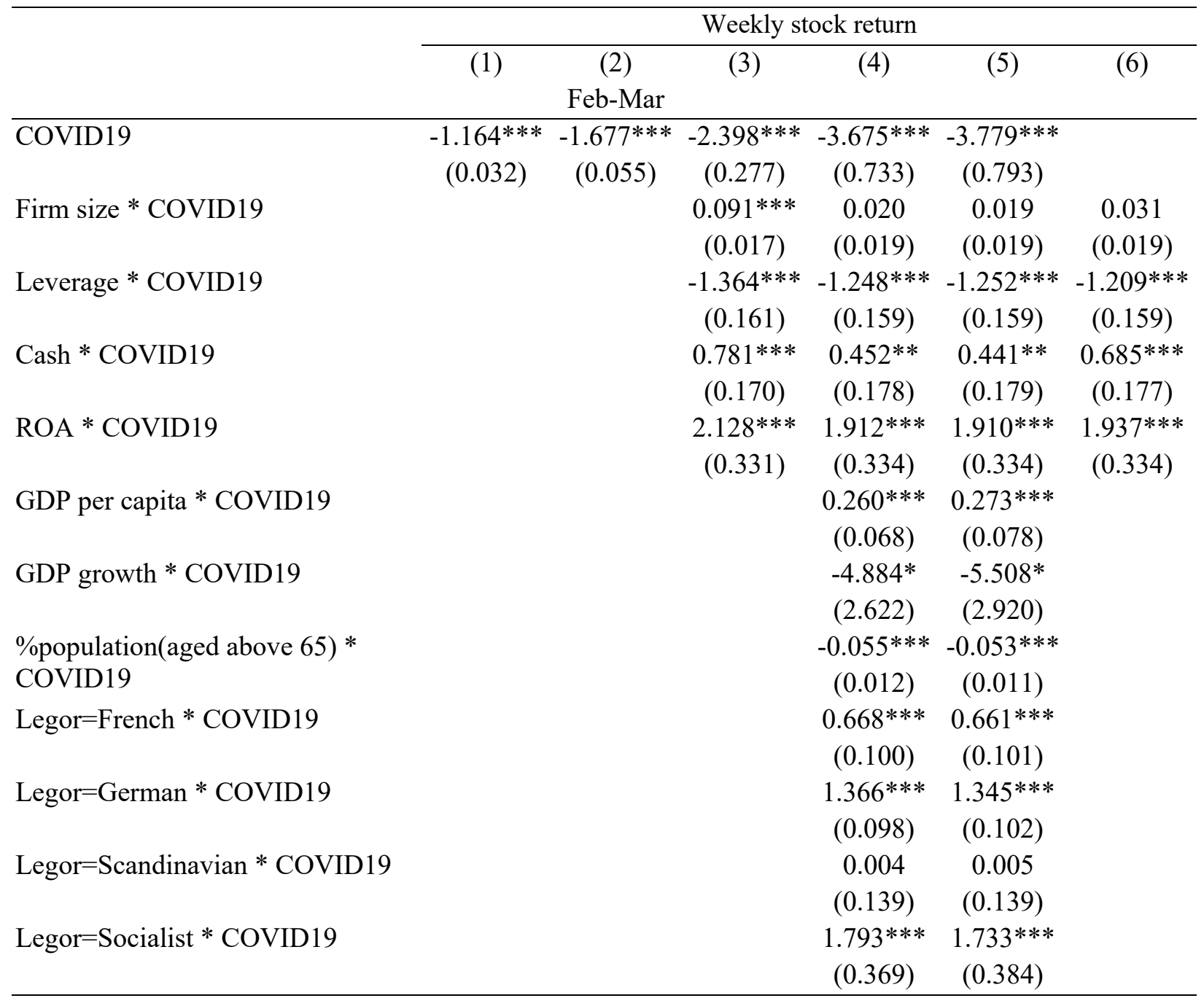




\begin{tabular}{lcccccc}
\hline & \multicolumn{7}{c}{ Weekly stock return } \\
\cline { 2 - 7 } & $(1)$ & $\begin{array}{c}(2) \\
\text { Feb-Mar }\end{array}$ & $(3)$ & $(4)$ & $(5)$ & $(6)$ \\
\hline Voice and Accountability * & & & & -0.036 \\
COVID19 & & & & $(0.071)$ & \\
Firm FE & $\mathrm{Y}$ & $\mathrm{Y}$ & $\mathrm{Y}$ & $\mathrm{Y}$ & $\mathrm{Y}$ & $\mathrm{Y}$ \\
Industry-time FE & $\mathrm{Y}$ & $\mathrm{Y}$ & $\mathrm{Y}$ & $\mathrm{Y}$ & $\mathrm{Y}$ & $\mathrm{Y}$ \\
Economy-time FE & $\mathrm{N}$ & $\mathrm{N}$ & $\mathrm{N}$ & $\mathrm{N}$ & $\mathrm{N}$ & $\mathrm{Y}$ \\
\hline Observations & 89,212 & 54,895 & 79,739 & 79,739 & 79,739 & 79,739 \\
Adjusted R-squared & 0.466 & 0.481 & 0.463 & 0.465 & 0.465 & 0.526 \\
\# of firms & 6,864 & 6,863 & 6,135 & 6,135 & 6,135 & 6,135 \\
\hline
\end{tabular}




\section{Table 3 Global supply networks and stock returns in response to COVID-19}

This table reports how a firm's international supply chain and customers exposure to COVID-19 shape stock price movements in response to the COVID-19 pandemic during the first quarter of 2020. The dependent variable is weekly stock return of each firm in a week. The key explanatory variable is COVID19 and its interactions with suppliers' and/or customers' exposure to the COVID-19. COVID19 is the weekly growth rate of the number of confirmed COVID-19 cases in an economy. In particular, For economy $c$ in week $t, C O V I D 19=\log (1+\#$ confirmed cases in week $t)-\log (1+\#$ confirmed cases in week $t$-1). Suppliers' exposure measures the extent to which a firm is exposed to COVID19 in foreign countries through its suppliers. For each firm $f$ in week $t$, we compute the weighted average of COVID19 of the firm's suppliers' countries, where a country is weighted by the total number of supplying companies in that country. A suppliers' country is a country in which firm $f$ has at least one supplying company. Customers' exposure measures the extent to which a firm is exposed to COVID19 in foreign countries through its customers. Economy traits * COVID19 denotes the interactions of COVID19 and a set of economy characteristics (GDP Per Capita, GDP Growth, \%population(aged above 65), and Legal origin). Firm traits * COVID19 represents the interactions of COVID19 and a set of firm financial conditions (i.e., Firm Size, Leverage, Cash, and ROA). Appendix Table A1 provides detailed variable definition. We include firm, industry by week, and/or economy by week fixed effects. Robust standard errors clustered at the firm level are reported in parentheses. ${ }^{* *}, * *, *$ denote significance levels at $1 \%, 5 \%$ and $10 \%$ respectively.

\begin{tabular}{lcccccc}
\hline & \multicolumn{5}{c}{ Weekly stock return } \\
\cline { 2 - 6 } & $(1)$ & $(2)$ & $(3)$ & $(4)$ & $(5)$ & $(6)$ \\
\hline COVID19 & $-3.246^{* * *}$ & & $-5.512^{* * *}$ & & $-4.563^{* * *}$ \\
& $(0.870)$ & & $(0.830)$ & & $(0.962)$ \\
Suppliers' exposure & $-0.451^{* * *}$ & $-0.298^{* * *}$ & & & $-0.265^{* * *}$ & $-0.212^{* *}$ \\
& $(0.074)$ & $(0.077)$ & & & $(0.094)$ & $(0.094)$ \\
Customers' exposure & & & $-0.614^{* * *}$ & $-0.437^{* * *}$ & $-0.597 * *$ & $-0.518^{* * *}$ \\
& & & $(0.097)$ & $(0.104)$ & $(0.119)$ & $(0.123)$ \\
Economy traits * COVID19) & $\mathrm{Y}$ & $\mathrm{N}$ & $\mathrm{Y}$ & $\mathrm{N}$ & $\mathrm{Y}$ & $\mathrm{N}$ \\
Firm traits * COVID19 & $\mathrm{Y}$ & $\mathrm{Y}$ & $\mathrm{Y}$ & $\mathrm{Y}$ & $\mathrm{Y}$ & $\mathrm{Y}$ \\
Firm FE & $\mathrm{Y}$ & $\mathrm{Y}$ & $\mathrm{Y}$ & $\mathrm{Y}$ & $\mathrm{Y}$ & $\mathrm{Y}$ \\
Industry-time FE & $\mathrm{Y}$ & $\mathrm{Y}$ & $\mathrm{Y}$ & $\mathrm{Y}$ & $\mathrm{Y}$ & $\mathrm{Y}$ \\
Economy-time FE & $\mathrm{N}$ & $\mathrm{Y}$ & $\mathrm{N}$ & $\mathrm{Y}$ & $\mathrm{N}$ & $\mathrm{Y}$ \\
\hline Observations & 59,262 & 59,262 & 64,684 & 64,684 & 50,436 & 50,436 \\
Adjusted R-squared & 0.476 & 0.531 & 0.491 & 0.544 & 0.492 & 0.541 \\
\# of firms & 4,559 & 4,559 & 4,976 & 4,976 & 3,880 & 3,880 \\
\hline
\end{tabular}




\section{Table 4 Corporate social responsibility and stock returns in response to COVID-19}

This table shows how firms' pre-2020 performance in environmental and social (E\&S) shape stock price movements in response to the COVID-19 pandemic during the first quarter of 2020. The dependent variable is weekly stock return of each firm in a week. The key explanatory variable is COVID19 and its interactions with the CSR score. COVID19 is the weekly growth rate of the number of confirmed COVID-19 cases in an economy. In particular, For economy $c$ in week $t$, COVID19 $=\log (1+\#$ confirmed cases in week $t)-\log (1+\#$ confirmed cases in week $t-1)$. CSR score is the average scores of Environmental, Social, and CSR Strategy, capturing the overall performance of corporate social responsibilities. Environmental score measures a firm's performance in environmental-related topics, including emission reduction, resource usage, and green innovation. Social score measures a firm's commitment to social activities, including employee welfare, human rights, community contribution, and product responsibilities. CSR Strategy score captures the degree to which a firm operationalizes and implements CSR strategies. Economy traits * COVID19 denotes the interactions of COVID19 and a set of economy characteristics (GDP Per Capita, GDP Growth, \%population(aged above 65), and Legal origin). Firm traits * COVID19 represents the interactions of COVID19 and a set of firm characteristics (i.e., Firm Size, Leverage, Cash, and ROA), Appendix Table A1 provides detailed variable definition. We include firm, industry by week, and/or economy by week fixed effects. Robust standard errors clustered at the firm level are reported in parentheses. $* * *, * *, *$ denote significance levels at $1 \%, 5 \%$ and $10 \%$ respectively.

\begin{tabular}{|c|c|c|c|c|c|c|c|c|}
\hline & \multicolumn{8}{|c|}{ Weekly stock return } \\
\hline & $(1)$ & $(2)$ & $(3)$ & (4) & $(5)$ & $(6)$ & (7) & $(8)$ \\
\hline \multirow[t]{2}{*}{ COVID19 } & $-3.435 * * *$ & & $-3.555 * * *$ & & $-3.616 * * *$ & & $-3.387 * * *$ & \\
\hline & $(0.738)$ & & $(0.736)$ & & $(0.734)$ & & $(0.737)$ & \\
\hline \multirow[t]{2}{*}{ CSR score * COVID19 } & $0.577 * * *$ & $0.548 * * *$ & & & & & & \\
\hline & $(0.156)$ & $(0.157)$ & & & & & & \\
\hline \multirow[t]{2}{*}{ Environmental * COVID19 } & & & $0.413 * * *$ & $0.356 * *$ & & & & \\
\hline & & & $(0.141)$ & $(0.142)$ & & & & \\
\hline \multirow[t]{2}{*}{ Social * COVID19 } & & & & & $0.373 * * *$ & $0.374 * *$ & & \\
\hline & & & & & $(0.142)$ & $(0.146)$ & & \\
\hline \multirow[t]{2}{*}{ CSR Strategy * COVID19 } & & & & & & & $0.362 * * *$ & $0.356^{* * *}$ \\
\hline & & & & & & & $(0.111)$ & $(0.110)$ \\
\hline Economy traits * COVID19 & $\mathrm{Y}$ & $\mathrm{N}$ & $\mathrm{Y}$ & $\mathrm{N}$ & Y & $\mathrm{N}$ & Y & $\mathrm{N}$ \\
\hline Firm traits $*$ COVID19 & $\mathrm{Y}$ & $\mathrm{Y}$ & $\mathrm{Y}$ & $\mathrm{Y}$ & Y & $\mathrm{Y}$ & Y & $\mathrm{Y}$ \\
\hline Firm FE & $\mathrm{Y}$ & $\mathrm{Y}$ & $\mathrm{Y}$ & Y & Y & Y & Y & Y \\
\hline Industry-time FE & $\mathrm{Y}$ & $\mathrm{Y}$ & $\mathrm{Y}$ & Y & $\mathrm{Y}$ & $\mathrm{Y}$ & Y & $\mathrm{Y}$ \\
\hline Economy-time FE & $\mathrm{N}$ & $\mathrm{Y}$ & $\mathrm{N}$ & $\mathrm{Y}$ & $\mathrm{N}$ & $\mathrm{Y}$ & $\mathrm{N}$ & $\mathrm{Y}$ \\
\hline Observations & 79,739 & 79,739 & 79,739 & 79,739 & 79,739 & 79,739 & 79,739 & 79,739 \\
\hline Adjusted R-squared & 0.465 & 0.526 & 0.465 & 0.526 & 0.465 & 0.526 & 0.465 & 0.526 \\
\hline \# of firms & 6,135 & 6,135 & 6,135 & 6,135 & 6,135 & 6,135 & 6,135 & 6,135 \\
\hline
\end{tabular}




\section{Table 5 Corporate governance and stock returns in response to COVID-19}

This table shows how corporate governance practices prior to 2020 shape stock price movements in response to the COVID-19 pandemic during the first quarter of 2020. The dependent variable is weekly stock return of a firm in a week. The key explanatory variable is COVID19 and its interactions with measures of corporate governance. COVID19 is the weekly growth rate of the number of confirmed COVID-19 cases in an economy. We use three sets of measures to measure corporate governance, including anti-takeover provisions, board, and CEO compensation. Anti-takeover provisions is measured by Anti-takeover Devices. Board-related measures include Board size policy, Board independence policy, and CEO-Chairman Duality. Executive compensation measures include Executive Compensation Performance Policy and Executive Compensation LT Objectives. Economy traits * COVID19 denotes the interactions of COVID19 and a set of economy characteristics (GDP Per Capita, GDP Growth, \%population(aged above 65), and Legal origin). Firm traits * COVID19 represents the interactions of COVID19 and a set of firm characteristics (i.e., Firm Size, Leverage, Cash, and ROA). Appendix Table A1 provides detailed variable definition. We include firm, industry by week, and/or economy by week fixed effects. Robust standard errors clustered at the firm level are reported in parentheses. ${ }^{* * *}, * *, *$ denote significance levels at $1 \%, 5 \%$ and $10 \%$ respectively.

\begin{tabular}{|c|c|c|c|c|c|c|}
\hline & \multicolumn{6}{|c|}{ Weekly stock return } \\
\hline & \multicolumn{2}{|c|}{$\begin{array}{l}\text { Anti-takeover } \\
\text { provisions }\end{array}$} & \multicolumn{2}{|c|}{ Board } & \multicolumn{2}{|c|}{$\begin{array}{l}\text { Executive } \\
\text { compensation }\end{array}$} \\
\hline & (1) & $(2)$ & (3) & (4) & $(5)$ & (6) \\
\hline COVID19 & $\begin{array}{l}-4.247 * * * \\
(0.744)\end{array}$ & & $\begin{array}{l}-3.928 * * * \\
(0.732)\end{array}$ & & $\begin{array}{c}-3.971 * * * \\
(0.731)\end{array}$ & \\
\hline Antitakeover Devices * COVID19 & $\begin{array}{c}-0.043 * * * \\
(0.015)\end{array}$ & $\begin{array}{c}-0.038 * * \\
(0.018)\end{array}$ & & & & \\
\hline Board Size Policy * COVID19 & & & $\begin{array}{c}0.028 \\
(0.076)\end{array}$ & $\begin{array}{c}0.119 \\
(0.078)\end{array}$ & & \\
\hline Board Independence Policy * & & & -0.039 & 0.004 & & \\
\hline COVID19 & & & $(0.062)$ & $(0.065)$ & & \\
\hline CEO-Chairman Duality * COVID19 & & & $\begin{array}{l}-0.008 \\
(0.062)\end{array}$ & $\begin{array}{c}0.099 \\
(0.065)\end{array}$ & & \\
\hline $\begin{array}{l}\text { Executive Compensation } \\
\text { Performance Policy } * \text { COVID19 }\end{array}$ & & & & & -0.106 & $\begin{array}{r}-0.060 \\
(0.083)\end{array}$ \\
\hline $\begin{array}{l}\text { Executive Compensation } \\
\text { LT Objectives * COVID19 }\end{array}$ & & & & & $\begin{array}{l}-0.130 \\
(0.109)\end{array}$ & $\begin{array}{l}-0.089 \\
(0.111)\end{array}$ \\
\hline Economy traits $*$ COVID19 & $\mathrm{Y}$ & $\mathrm{N}$ & $\mathrm{Y}$ & $\mathrm{N}$ & $\mathrm{Y}$ & $\mathrm{N}$ \\
\hline Firm traits $*$ COVID19 & $\mathrm{Y}$ & Y & $\mathrm{Y}$ & $\mathrm{Y}$ & $\mathrm{Y}$ & $\mathrm{Y}$ \\
\hline Firm FE & $\mathrm{Y}$ & $\mathrm{Y}$ & $\mathrm{Y}$ & $\mathrm{Y}$ & $\mathrm{Y}$ & $\mathrm{Y}$ \\
\hline Industry-time FE & $\mathrm{Y}$ & Y & $\mathrm{Y}$ & $\mathrm{Y}$ & $\mathrm{Y}$ & $\mathrm{Y}$ \\
\hline Economy-time FE & $\mathrm{N}$ & $\mathrm{Y}$ & $\mathrm{N}$ & $\mathrm{Y}$ & $\mathrm{N}$ & $\mathrm{Y}$ \\
\hline Observations & 79,726 & 79,726 & 78,517 & 78,517 & 78,517 & 78,517 \\
\hline Adjusted R-squared & 0.465 & 0.526 & 0.465 & 0.526 & 0.465 & 0.526 \\
\hline \# of firms & 6,134 & 6,134 & 6,041 & 6,041 & 6,041 & 6,041 \\
\hline F-statistics of Joint Significance Test & 8.89 & 4.47 & 0.17 & 1.56 & 1.63 & 0.59 \\
\hline
\end{tabular}




\section{Table 6 Ownership structure and stock returns in response to COVID-19}

This table shows how pre-2020 ownership structure shape stock price movements in response to the COVID-19 pandemic during the first quarter of 2020. The dependent variable is weekly stock return of each firm in a week. The key explanatory variable is COVID19 and its interactions with measures of ownership structure. COVID19 is the weekly growth rate of the number of confirmed COVID-19 cases in an economy. In particular, For economy $c$ in week $t$, COVID19= $\log (1+\#$ confirmed cases in week $t)-\log (1+\#$ confirmed cases in week $t-1)$. We measure a firm's ownership structure based on different types of blockholders, namely Investment Advisor/Research Firm, hedge fund (Hedge Fund), Bank/Trust/Insurance/Pension Fund, individual investors (Individual), corporation or holding company (Corporation), government agency (Government), sovereign wealth fund (Sovereign Wealth Fund), and private equity and venture capital $(P E / V C)$. For each category, we calculate: (1) the sum of ownership of all blockholders, (2) the ownership of the largest blockholder, and (3) the sum of ownership of the five largest blockholders. Economy traits * COVID19 denotes the interactions of COVID19 and a set of economy characteristics (GDP Per Capita, GDP Growth, \%population(aged above 65), and Legal origin). Firm traits * COVID19 represents the interactions of COVID19 and a set of firm characteristics (i.e., Firm Size, Leverage, Cash, and ROA). Appendix Table A1 provides detailed variable definition. We include firm, industry by week, and/or economy by week fixed effects. Robust standard errors clustered at the firm level are reported in parentheses. $* * *, * *,{ }^{*}$ denote significance levels at $1 \%, 5 \%$ and $10 \%$ respectively.

\begin{tabular}{|c|c|c|c|c|c|c|}
\hline & \multicolumn{6}{|c|}{ Weekly stock return } \\
\hline & \multicolumn{2}{|c|}{$\begin{array}{c}\text { Ownership of all } \\
\text { blockholders }\end{array}$} & \multicolumn{2}{|c|}{$\begin{array}{l}\text { Ownership of the largest } \\
\text { blockholders }\end{array}$} & \multicolumn{2}{|c|}{$\begin{array}{l}\text { Ownership of the top5 } \\
\text { blockholders }\end{array}$} \\
\hline & (1) & $(2)$ & (3) & (4) & $(5)$ & (6) \\
\hline COVID19 & $\begin{array}{l}-4.476^{* * *} \\
(0.744)\end{array}$ & & $\begin{array}{l}-4.127 * * * \\
(0.735)\end{array}$ & & $\begin{array}{l}-4.448^{* * *} \\
(0.743)\end{array}$ & \\
\hline Investment Advisor/Research firm * & 0.205 & -0.018 & 0.449 & 0.360 & 0.277 & 0.054 \\
\hline COVID19 & $(0.295)$ & $(0.318)$ & $(0.553)$ & $(0.567)$ & $(0.308)$ & $(0.332)$ \\
\hline Hedge Fund * COVID19 & $\begin{array}{c}-2.386^{* * *} \\
(0.839)\end{array}$ & $\begin{array}{c}-2.478 * * * \\
(0.847)\end{array}$ & $\begin{array}{c}-2.414^{* *} \\
(1.134)\end{array}$ & $\begin{array}{c}-2.428 * * \\
(1.137)\end{array}$ & $\begin{array}{l}-2.378 * * * \\
(0.874)\end{array}$ & $\begin{array}{c}-2.475^{* * *} \\
(0.884)\end{array}$ \\
\hline $\begin{array}{l}\text { Bank/Trust/Insurance/Pension Fund * } \\
\text { COVID19 }\end{array}$ & $\begin{array}{c}1.242 \\
(0.837)\end{array}$ & $\begin{array}{c}0.207 \\
(0.828)\end{array}$ & $\begin{array}{l}-0.592 \\
(1.106)\end{array}$ & $\begin{array}{l}-0.469 \\
(0.989)\end{array}$ & $\begin{array}{l}1.224 \\
(0.839)\end{array}$ & $\begin{array}{c}0.119 \\
(0.826)\end{array}$ \\
\hline Individual $*$ COVID19 & $\begin{array}{c}0.405 \\
(0.253)\end{array}$ & $\begin{array}{c}0.254 \\
(0.256)\end{array}$ & $\begin{array}{c}0.388 \\
(0.302)\end{array}$ & $\begin{array}{c}0.326 \\
(0.307)\end{array}$ & $\begin{array}{l}0.395 \\
(0.256)\end{array}$ & $\begin{array}{c}0.242 \\
(0.260)\end{array}$ \\
\hline Corporation * COVID19 & $\begin{array}{c}0.674 * * * \\
(0.143)\end{array}$ & $\begin{array}{c}0.651^{* * *} \\
(0.147)\end{array}$ & $\begin{array}{c}0.647 * * * \\
(0.156)\end{array}$ & $\begin{array}{l}0.678 * * * \\
(0.158)\end{array}$ & $\begin{array}{c}0.673 * * * \\
(0.143)\end{array}$ & $\begin{array}{c}0.648^{* * *} \\
(0.148)\end{array}$ \\
\hline Government * COVID19 & $\begin{array}{c}0.810^{* *} \\
(0.340)\end{array}$ & $\begin{array}{l}-0.025 \\
(0.320)\end{array}$ & $\begin{array}{l}0.715^{* *} \\
(0.354)\end{array}$ & $\begin{array}{l}-0.012 \\
(0.324)\end{array}$ & $\begin{array}{c}0.815^{* *} \\
(0.341)\end{array}$ & $\begin{array}{c}-0.026 \\
(0.320)\end{array}$ \\
\hline Sovereign Wealth Fund * COVID19 & $\begin{array}{c}2.657 * * * \\
(0.870)\end{array}$ & $\begin{array}{c}0.624 \\
(0.850)\end{array}$ & $\begin{array}{c}2.652 * * * \\
(1.024)\end{array}$ & $\begin{array}{c}0.739 \\
(0.996)\end{array}$ & $\begin{array}{c}2.750 * * * \\
(0.870)\end{array}$ & $\begin{array}{c}0.719 \\
(0.851)\end{array}$ \\
\hline $\mathrm{PE} / \mathrm{VC} * \mathrm{COVID} 19$ & $\begin{array}{l}-0.256 \\
(0.771)\end{array}$ & $\begin{array}{l}-0.362 \\
(0.776)\end{array}$ & $\begin{array}{c}0.119 \\
(0.842)\end{array}$ & $\begin{array}{c}0.107 \\
(0.840)\end{array}$ & $\begin{array}{c}-0.181 \\
(0.771)\end{array}$ & $\begin{array}{l}-0.285 \\
(0.776)\end{array}$ \\
\hline
\end{tabular}




\begin{tabular}{|c|c|c|c|c|c|c|}
\hline & \multicolumn{6}{|c|}{ Weekly stock return } \\
\hline & \multicolumn{2}{|c|}{$\begin{array}{l}\text { Ownership of all } \\
\text { blockholders }\end{array}$} & \multicolumn{2}{|c|}{$\begin{array}{l}\text { Ownership of the largest } \\
\text { blockholders }\end{array}$} & \multicolumn{2}{|c|}{$\begin{array}{l}\text { Ownership of the top } 5 \\
\text { blockholders }\end{array}$} \\
\hline & (1) & (2) & (3) & (4) & $(5)$ & $(6)$ \\
\hline Economy traits * COVID19 & $\mathrm{Y}$ & $\mathrm{N}$ & $\mathrm{Y}$ & $\mathrm{N}$ & $\mathrm{Y}$ & $\mathrm{N}$ \\
\hline Firm traits * COVID19 & Y & $\mathrm{Y}$ & $\mathrm{Y}$ & $\mathrm{Y}$ & $\mathrm{Y}$ & $\mathrm{Y}$ \\
\hline Firm FE & Y & $\mathrm{Y}$ & $\mathrm{Y}$ & $\mathrm{Y}$ & $\mathrm{Y}$ & $\mathrm{Y}$ \\
\hline Industry-time FE & $\mathrm{Y}$ & $\mathrm{Y}$ & $\mathrm{Y}$ & $\mathrm{Y}$ & $\mathrm{Y}$ & $\mathrm{Y}$ \\
\hline Economy-time FE & $\mathrm{N}$ & $\mathrm{Y}$ & $\mathrm{N}$ & $\mathrm{Y}$ & $\mathrm{N}$ & $\mathrm{Y}$ \\
\hline Observations & 79,739 & 79,739 & 79,739 & 79,739 & 79,739 & 79,739 \\
\hline Adjusted R-squared & 0.465 & 0.526 & 0.465 & 0.526 & 0.465 & 0.526 \\
\hline \# of firms & 6,135 & 6,135 & 6,135 & 6,135 & 6,135 & 6,135 \\
\hline
\end{tabular}




\section{Table 7 Corporate characteristics: Simultaneous analyses}

This table reports the horserace tests among a firm's financial conditions, international supply chain, E\&S performance, corporate governance and ownership structure. The dependent variable is weekly stock return of each firm in a week. The key explanatory variable is COVID19 and its interactions with one of the firm-level characteristics, namely firm financial conditions (Firm Size, Leverage, Cash, and ROA), environmental and social performance (CSR score), COVID-exposure through international supply networks (Suppliers' Exposure to COVID19 and Customers' Exposure to COVID19), corporate governance (Anti-takeover Devices), ownership structure (the ownership of Hedge Fund and Corporation). COVID19 is the weekly growth rate of the number of confirmed COVID-19 cases in an economy. Firm traits * COVID19 represents the interactions of COVID19 and a set of firm characteristics (i.e., Firm Size, Leverage, Cash, and ROA). We include firm, industry by week, and economy by week fixed effects in all columns. Table A1 provides detailed variable definition. Robust standard errors clustered at the firm level are reported in parentheses. $* * *, * *, *$ denote significance levels at $1 \%, 5 \%$ and $10 \%$ respectively.

\begin{tabular}{|c|c|c|c|}
\hline & \multicolumn{3}{|c|}{ Weekly stock return } \\
\hline & $\begin{array}{l}\text { Supply chain } \\
+ \text { E\&S } \\
\text { (1) }\end{array}$ & $\begin{array}{l}\text { Supply chain } \\
+ \text { E\&S } \\
+ \text { Governance } \\
\text { (2) }\end{array}$ & $\begin{array}{c}\text { Supply chain } \\
+ \text { E\&S } \\
+ \text { Governance } \\
+ \text { Ownership } \\
\text { (3) }\end{array}$ \\
\hline Firm size * COVID19 & $\begin{array}{c}0.037 \\
(0.033)\end{array}$ & $\begin{array}{c}0.040 \\
(0.033)\end{array}$ & $\begin{array}{c}0.037 \\
(0.033)\end{array}$ \\
\hline Leverage * COVID19 & $\begin{array}{c}-1.313^{* * *} \\
(0.233)\end{array}$ & $\begin{array}{c}-1.306^{* * *} \\
(0.234)\end{array}$ & $\begin{array}{c}-1.244^{* * *} \\
(0.230)\end{array}$ \\
\hline Cash * COVID19 & $\begin{array}{c}1.421 * * * \\
(0.276)\end{array}$ & $\begin{array}{c}1.483 * * * \\
(0.275)\end{array}$ & $\begin{array}{c}1.571 * * * \\
(0.277)\end{array}$ \\
\hline ROA * COVID19 & $\begin{array}{c}2.830 * * * \\
(0.451)\end{array}$ & $\begin{array}{c}2.732 * * * \\
(0.453)\end{array}$ & $\begin{array}{c}2.649 * * * \\
(0.450)\end{array}$ \\
\hline Suppliers' exposure & $\begin{array}{c}-0.218 * * \\
(0.094)\end{array}$ & $\begin{array}{c}-0.219 * * \\
(0.094)\end{array}$ & $\begin{array}{c}-0.223 * * \\
(0.093)\end{array}$ \\
\hline Customers' exposure & $\begin{array}{c}-0.522 * * * \\
(0.123)\end{array}$ & $\begin{array}{c}-0.527 * * * \\
(0.123)\end{array}$ & $\begin{array}{c}-0.518^{* * *} \\
(0.123)\end{array}$ \\
\hline CSR score $*$ COVID19 & $\begin{array}{c}0.589 * * \\
(0.239)\end{array}$ & $\begin{array}{c}0.607 * * \\
(0.239)\end{array}$ & $\begin{array}{c}0.581 * * \\
(0.237)\end{array}$ \\
\hline Antitakeover Devices * COVID19 & & $\begin{array}{c}-0.052 * * \\
(0.024)\end{array}$ & $\begin{array}{c}-0.052 * * \\
(0.023)\end{array}$ \\
\hline Hedge Fund * COVID19 & & & $\begin{array}{c}-2.803 * * * \\
(1.064)\end{array}$ \\
\hline Corporation * COVID19 & & & $\begin{array}{c}0.876^{* * *} \\
(0.208)\end{array}$ \\
\hline Firm FE & Y & $\mathrm{Y}$ & $\mathrm{Y}$ \\
\hline Industry-time FE & Y & Y & $\mathrm{Y}$ \\
\hline Economy-time FE & Y & $\mathrm{Y}$ & $\mathrm{Y}$ \\
\hline Observations & 50,436 & 50,436 & 50,436 \\
\hline Adjusted R-squared & 0.541 & 0.541 & 0.542 \\
\hline \# of firms & 3,880 & 3,880 & 3,880 \\
\hline
\end{tabular}




\section{Appendix}

Table A1. Variable Definition

\begin{tabular}{|c|c|c|}
\hline Variable & Definition & Source \\
\hline Weekly stock return & $\begin{array}{l}\text { The weekly stock return of each firm in a week is calculated by using dividend- } \\
\text { adjusted closing prices on the last trading day of the week. }\end{array}$ & Thomson Reuters Datastream \\
\hline COVID19 & $\begin{array}{l}\text { The weekly growth rate of the number of confirmed COVID-19 cases in an } \\
\text { economy. For economy } c \text { in week } t, \text { COVID } 19=\log (1+\# \text { confirmed cases in } \\
\text { week } t)-\log (1+\# \text { confirmed cases in week } t-1)\end{array}$ & $\begin{array}{l}\text { Center for Systems Science and } \\
\text { Engineering at Johns Hopkins } \\
\text { University }\end{array}$ \\
\hline \multicolumn{3}{|c|}{ 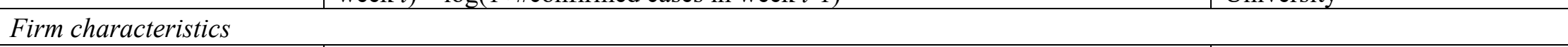 } \\
\hline Firm size & The natural logarithm of the book value of total assets. & Thomson Reuters Worldscope \\
\hline Leverage & The ratio of total debt divided by total assets. & Thomson Reuters Worldscope \\
\hline Cash & The total amount of cash and short-term investments divided by total assets. & Thomson Reuters Worldscope \\
\hline ROA & The ratio of net income to total assets. & Thomson Reuters Worldscope \\
\hline Suppliers' exposure & $\begin{array}{l}\text { For each firm } f \text { in week } t \text {, the weighted average of COVID19 among the foreign } \\
\text { countries in which the firm's suppliers are situated, where the weights are the } \\
\text { proportion of the firm's pre-pandemic supplies from a country and COVID19 } \\
\text { varies weekly as defined above. }\end{array}$ & FactSet Revere \\
\hline Customers' exposure & $\begin{array}{l}\text { For each firm } f \text { in week } t \text {, the weighted average of COVID19 among the foreign } \\
\text { countries in which the firm sells its products, where the weights are the } \\
\text { proportion of the firm's pre-pandemic revenues in a country and COVID19 } \\
\text { varies weekly as defined above. }\end{array}$ & FactSet Revere \\
\hline CSR Score & $\begin{array}{l}\text { The average of the indexes of Environmental, Social, and CSR Strategy, } \\
\text { measuring a firm's commitment to (1) the environment, including resource use, } \\
\text { emissions, and green innovation, (2) non-shareholder stakeholders and social } \\
\text { themes, including employee welfare, human rights, and the ethical treatment of } \\
\text { customers, suppliers, and the communities in which the firm operates, and (3) } \\
\text { operationalizing and implementing CSR activities. }\end{array}$ & Thomson Reuters ASSET4 \\
\hline Environmental & $\begin{array}{l}\text { The Environmental score comprises three components, resource usage, emission } \\
\text { reduction, and green innovation, reflecting (a) a company's performance and } \\
\text { capacity to reduce the use of materials, energy or water, and to find more eco- } \\
\text { efficient solutions by improving supply chain management; commitment and } \\
\text { effectiveness towards reducing environmental emission in the production and } \\
\text { operational processes, and capacity to reduce the environmental costs and }\end{array}$ & Thomson Reuters ASSET4 \\
\hline
\end{tabular}




\begin{tabular}{|c|c|c|}
\hline Variable & Definition & Source \\
\hline & $\begin{array}{l}\text { burdens for its customers, thereby creating new market opportunities through } \\
\text { new environmental technologies and processes or eco-designed products }\end{array}$ & \\
\hline Social & $\begin{array}{l}\text { The Social index aggregates information on the extent to which firms enhance } \\
\text { employee welfare (Workforce), promote human rights (Human Rights), engage } \\
\text { in community development (Community), and fulfill their responsibilities to } \\
\text { consumers (Product Responsibility). }\end{array}$ & Thomson Reuters ASSET4 \\
\hline CSR Strategy & $\begin{array}{l}\text { CSR Strategy index includes information on the degree to which firms organize, } \\
\text { operationalize, and implement CSR strategies. It covers whether firms (a) have } \\
\text { a CSR sustainability committee, (b) publish CSR/Health\&Safety/Sustainability } \\
\text { reports, and whether those reports are published in accordance with the Global } \\
\text { Report Initiative Guidelines, (c) have an external audit on CSR related issues, } \\
\text { (d) explicitly integrate financial and extra-financial factors in the management } \\
\text { discussion and analysis section of the annual reports, and (e) explain how it } \\
\text { engages with its stakeholders. }\end{array}$ & Thomson Reuters ASSET4 \\
\hline Anti-takeover Devices & $\begin{array}{l}\text { Equals the number of anti-takeover devices in place if there are more than two } \\
\text { anti-takeover devices and zero otherwise. The data cover an array of anti- } \\
\text { takeover devices, including poison pills, classified boards, blank checks, } \\
\text { supermajority votes, dual-class shares, golden parachutes, limited shareholder } \\
\text { rights to call for special meetings, cumulative voting rights, pre-emptive rights, } \\
\text { company cross shareholdings, confidential voting policies, limited director } \\
\text { liability, shareholder approval of significant transactions, fair price provisions, } \\
\text { limitations on removal of directors, advance notice for shareholder proposals, } \\
\text { written consent requirements, and expanded constituency provisions }\end{array}$ & Thomson Reuters ASSET4 \\
\hline Board Size Policy & Equals one if the firm has a policy regarding the size of its board, zero otherwise. & Thomson Reuters ASSET4 \\
\hline Board Independence Policy & $\begin{array}{l}\text { Equals one if the firm has a policy regarding the independence of its board, zero } \\
\text { otherwise. }\end{array}$ & Thomson Reuters ASSET4 \\
\hline CEO-Chairman Duality & $\begin{array}{l}\text { Equals one if an individual holds (or has held) both the position of CEO and } \\
\text { chair of the board of this company, zero otherwise. }\end{array}$ & Thomson Reuters ASSET4 \\
\hline $\begin{array}{l}\text { Executive Compensation } \\
\text { Performance Policy }\end{array}$ & $\begin{array}{l}\text { Equals one if the firm has a performance-based compensation policy for the } \\
\text { higher-level executives and board members, zero otherwise. }\end{array}$ & Thomson Reuters ASSET4 \\
\hline $\begin{array}{l}\text { Executive Compensation } \\
\text { LT Objectives }\end{array}$ & $\begin{array}{l}\text { Equals one if executive and board compensation are partially linked to longer- } \\
\text { term objectives, i.e., objectives that are more than two years in the future, zero } \\
\text { otherwise. }\end{array}$ & Thomson Reuters ASSET4 \\
\hline
\end{tabular}




\begin{tabular}{|c|c|c|}
\hline Variable & Definition & Source \\
\hline $\begin{array}{l}\text { Investment } \\
\text { Advisor/Research firm }\end{array}$ & $\begin{array}{l}\text { Total percentage of blockholders' shareholdings held by mutual funds, } \\
\text { investment and asset management companies, such as Vanguard, Fidelity, } \\
\text { BlackRock, and the investment bank, asset management, and securities of } \\
\text { financial companies. }\end{array}$ & Thomson Reuters Ownership \\
\hline Hedge Fund & $\begin{array}{l}\text { Total percentage of blockholders' shareholdings held by hedge fund such as } \\
\text { Citadel, Two Sigma, and Renaissance Technologies. }\end{array}$ & Thomson Reuters Ownership \\
\hline $\begin{array}{l}\text { Bank/Trust/Insurance/Pensi } \\
\text { on Fund }\end{array}$ & $\begin{array}{l}\text { Total percentage of blockholders' shareholdings held by traditional financial } \\
\text { institutions, including commercial banks, trust companies, pension funds, and } \\
\text { insurance companies. }\end{array}$ & Thomson Reuters Ownership \\
\hline Individual & Total percentage of blockholders' shareholdings held by individual investors. & Thomson Reuters Ownership \\
\hline Corporation & $\begin{array}{l}\text { Total percentage of blockholders' shareholdings held by holding companies and } \\
\text { non-financial corporations. }\end{array}$ & Thomson Reuters Ownership \\
\hline Government & Total percentage of blockholders' shareholdings held by government agencies. & Thomson Reuters Ownership \\
\hline Sovereign Wealth Fund & Total percentage of blockholders' shareholdings held by sovereign wealth fund. & Thomson Reuters Ownership \\
\hline $\mathrm{PE} / \mathrm{VC}$ & $\begin{array}{l}\text { Total percentage of blockholders' shareholdings held by private equity and } \\
\text { venture capital. }\end{array}$ & Thomson Reuters Ownership \\
\hline \multicolumn{3}{|l|}{ Economy Traits } \\
\hline GDP per capita & The natural logarithm of GDP per capita in 2018. & World Development Indicators \\
\hline GDP growth & The growth rate of GDP, measured in 2018 . & World Development Indicators \\
\hline $\begin{array}{l}\text { \%population(aged above } \\
65 \text { ) }\end{array}$ & $\begin{array}{l}\text { The percentage of population aged above } 65 \text { among the total population of an } \\
\text { economy in } 2018 \text {. }\end{array}$ & World Development Indicators \\
\hline Legal origin & $\begin{array}{l}\text { A set of dummy variables equal to one if an economy's legal heritage is } \\
\text { Common, French, German, Scandinavian or Socialist law, respectively. }\end{array}$ & La Porta et al. (2008) \\
\hline Voice and Accountability & $\begin{array}{l}\text { The ability of individuals in an economy to choose their governments, express } \\
\text { their views freely, associate with whom they choose, association, experience a } \\
\text { free press, and hold government officials accountable. Higher values indicate } \\
\text { greater individual voice in public affairs and greater press freedom. }\end{array}$ & World Governance Indicators \\
\hline
\end{tabular}


Table A2 Corporate governance and stock returns in response to the COVID-19 pandemic, robustness

This table shows how pre-2020 corporate governance shapes stock price movements in response to the COVID-19 pandemic. The analysis is similar to Table 5 in the main text except that we include one governance measure in each regression. The dependent variable is weekly stock return of a firm in a week. The key explanatory variable is COVID19 and its interactions with measures of corporate governance. COVID19 is the weekly growth rate of the number of confirmed COVID-19 cases in an economy. Corporate governance measures include Board size policy, Board independence policy, CEO-Chairman Duality, Executive Compensation Performance Policy and Executive Compensation LT Objectives. Firm traits * COVID19 represents the interactions of COVID19 and a set of firm characteristics (i.e., Firm Size, Leverage, Cash, and ROA). Appendix Table A1 provides detailed variable definition. We include firm, industry by week, and economy by week fixed effects in all columns. Robust standard errors clustered at the firm level are reported in parentheses. $* * *, * *, *$ denote significance levels at $1 \%, 5 \%$ and $10 \%$ respectively.

\begin{tabular}{|c|c|c|c|c|c|}
\hline & \multicolumn{5}{|c|}{ Weekly stock return } \\
\hline & (1) & (2) & (3) & (4) & (5) \\
\hline Board Size Policy * COVID19 & $\begin{array}{c}0.119 \\
(0.077)\end{array}$ & & & & \\
\hline Board Independence Policy * COVID19 & & $\begin{array}{c}0.018 \\
(0.064)\end{array}$ & & & \\
\hline CEO-Chairman Duality * COVID19 & & & $\begin{array}{c}0.099 \\
(0.065)\end{array}$ & & \\
\hline Executive Compensation Performance Policy * COVID19 & & & & $\begin{array}{c}-0.061 \\
(0.083)\end{array}$ & \\
\hline Executive Compensation LT Objectives * COVID19 & & & & & $\begin{array}{l}-0.089 \\
(0.111)\end{array}$ \\
\hline Firm traits * COVID19 & Y & Y & Y & Y & Y \\
\hline Firm FE & Y & Y & Y & Y & Y \\
\hline Industry-time FE & $\mathrm{Y}$ & Y & Y & Y & Y \\
\hline Economy-time FE & $\mathrm{Y}$ & $\mathrm{Y}$ & $\mathrm{Y}$ & $\mathrm{Y}$ & $\mathrm{Y}$ \\
\hline Observations & 78,517 & 78,517 & 78,517 & 78,517 & 78,517 \\
\hline Adjusted R-squared & 0.526 & 0.526 & 0.526 & 0.526 & 0.526 \\
\hline \# of firms & 6,041 & 6,041 & 6,041 & 6,041 & 6,041 \\
\hline
\end{tabular}

